Chapter 6

\title{
Alternative Weed Control Methods: A Review
}

\author{
G.R. Mohammadi \\ Additional information is available at the end of the chapter \\ http://dx.doi.org/10.5772/54164
}

\section{Introduction}

Weed interference is one of the most important limiting factors which decrease crop yields and consequently global food production. Weed represent about $0.1 \%$ of the world flora and in agroecosystems, weeds and crops have co-evolved together right from the prehistoric times as revealed by pollen analysis studies (Cousens and Mortimer 1995). Weed can suppress crop yield by competing for environmental resources like water, light and nutrients and production of allelopathic compounds. Therefore, weed management have been a major challenge for crop producers from the start of agriculture. At the earlier times, since no synthetic chemicals were known, weed control was achieved by some methods such as hand weeding, crop rotation, polyculture and other management practices that were low input but sustainable. With the discovery of synthetic herbicides in the early 1930s, there was a shift in control methods toward high input and target-oriented ones (Singh et al. 2003).

However, herbicide-reliant weed control methods can cause high costs for crop producers due to the consumption of fossil fuels (the non-renewable energy resources) (Lybecker et al. 1988). Moreover, ground and surface water pollution by these synthetic chemicals are causes for concern (Hallberg 1989). Fast-developing herbicide-resistant ecotypes of weeds due to increased herbicide application is another serious threat for agriculture production (Holt and LeBaron 1990). Therefore, there is an urgent need to develop alternative weed control methods for use in agroecosystems. Many studies have revealed that the alternative methods such as the use of allelopathy phenomenon, cover crops and living mulches, competitive crop cultivars, suitable nutrient management, etc. can be proposed as the low cost, effective and eco-friendly practices for sustainable weed management in cropping systems. In this chapter, the most important alternative weed control methods are discussed. 


\section{Allelopathy}

The term allelopathy was first introduced by Hans Molisch in 1937 and refers to chemical interactions among plants, including those mediated by microorganisms. Rice (1984) defined allelopathy as the effects of one plant (including microorganisms) on another plant through the release of a chemical compounds into the environment. Allelopathy can play a beneficial role in various cropping systems such as mixed cropping, multiple cropping, cover cropping, crop rotations, and minimum and no-tillage systems. The exploitation of allelopathy in agricultural practices as a tool for weed control has shown weed reduction, pathogen prevention and soil enrichment (Kohli et al., 1998).

\subsection{Ways by which allelopathy can be used to control weeds in cropping sysyems}

In general, the use of allelopathy as a tool to control weeds can be achieved in different ways:

1. Use of crop cultivars with allelopathic properties.

2. Application of residues and straw of allelopathic crops as mulches or incorporated into the soil.

3. Use of an allelopathic crop in a rotational sequence.

4. Application of allelochemicals or modified allelochemicals as herbicides (Kruse et al. 2000).

5. Modification of crops to enhance their allelopathic effects.

\subsubsection{Use of crop cultivars with allelopathic properties}

It's clear that the crop cultivars differ in their allelopathic ability and thus superior cultivars can be selected for weed management programs (Wu et al. 1999; Olofsdotter et al. 2002). Differences in allelopathic potential between genotypes has been investigated among accessions (genetical different lines or strains of a species) of barley, cucumber (Cucumis sativus), oats, soybean (Glycine max), sunflower, sorghum (Sorghum bicolor), rice and wheat (Copaja et al. 1999, Dilday et al. 1994, Narwal 1996, Miller 1996, Yoshida et al. 1993, Wu et al. 1998).

In a study on 3000 accessions of Avena spp. Fay and Duke (1977) found that four accessions apparently exuded up to three times as much scopoletin (a chemical identified as phytotoxic) as a standard oat cultivar. When one of the accessions were grown in sand culture with wild mustard (Brassica kaber), the growth of the mustard was significantly less than when it was grown with an accession that exuded a lower amount of scopoletin. In a field experiment, 1000 accessions of rice were screened for allelopathic activity against the two weedy species, barnyardgrass (Echinochloa crus-galli Beauv) and Cyperus difformis. Of these, 45 accessions showed allelopathic activity against one of the weeds and five accessions inhibited both species (Olofsdotter et al. 1997). Dilday et al. (2001) evaluated 12,000 rice accessions from 110 countries for allelopathy to ducksalad [Heteranthera limosa (S.w.) Willd.] and about 
5000 have been assessed for allelopathy to redstem (Ammannia coccinea) and barnyardgrass. Results indicated that among them, 145 accessions were allelopathic to ducksalad and redstem and 94 accessions demonstrated apparent allelopathic activity to barnyardgrass.

Many weed species are most susceptible to allelochemicals in the seed and seedling stages. Therefore, the ideal allelopathic cultivar must therefore release allelochemicals in bioactive concentrations before the target weeds grow to old. Knowledge about both the critical developmental stage where the crop starts releasing allelochemicals and the critical sensitive stage of the target weeds is therefore essential (Inderjit and Olofsdotter 1998).

\subsubsection{Application of residues and straw of allelopathic crops}

Weed suppressive effects of crop residues have been explained by different mechanisms, including initial low nitrogen availability following cover crop incorporation (Dyck and Liebman 1994; Kumar et al. 2008; Samson 1991), mulch effects (Mohler 1996; Mohler and Callaway 1991; Mohler and Teasdale 1993), stimulation of pathogens or predators of weed seeds (Carmona and Landis 1999; Conklin et al. 2002; Davis and Liebman 2003; Gallandt et al. 2005; Kremer 1993), and allelopathy (Chou 1999; Weston 1996).

Allelopathic compounds released from crop residues during decomposition can reduce both emergence and growth of weeds. Allelochemicals can be released either through leaching, decomposition of residues, volatilization or root exudation (Chou 1999). In production systems with no-till or conservation tillage that leave nearly all crop residues on the soil surface, the release of allelochemicals from both the growing plants and during residue decomposition could be advantageous (Kruse et al. 2000).

Barnes and Putnam (1983) reported that rye residue used as mulch reduced total weed biomass by $63 \%$. It was found that disappearance of rye allelochemicals was more closely related to weed suppression than to the disappearance of rye residues. Especially due to the massive production of biomass, rye has the potential to influence the growth of succeeding plant species through the release of allelochemicals from the residue (Barnes et al. 1985).

Wheat residues suppress weeds due to the physical effect and to the production of allelochemicals (Petho 1992). their allelopathic effects was positively correlated with the total phenolic content in the tissue of the wheat cultivars (Wu et al 1998). Hydroxamic acids have also been identified in shoot and root tissue of wheat.

The residues of barley have also been associated with phytotoxicity (Overland 1966, Lovett and Hoult 1995). Phytotoxic phenolic compounds, including ferulic, vanillic and phydroxybenzoic acids, have been identified in barley (Börner 1960). The two alkaloids, gramine and hordenine have been confirmed to play an important role in the phytotoxic ability of barley (Lovett and Hoult 1995, Overland 1966). In a study, allelopathic compounds released from residues of barley apparently inhibit the emergence of yellow foxtail (Setaria glauca) (Creamer et al. 1996). 
In another study, the use of sorghum plant tissues as a mulch or incorporated into the soil led to the reduced weed growth in corn field (Mohammadi et al. 2009). This can be attributed to the allelopathic compounds released from the sorghum plant tissues.

\subsubsection{Use of an allelopathic crop in a rotational sequence}

The entrance of allelopathic crops into the crop rotations can effectively control weeds. In a study, under reduced or no-till condition a considerable reduction in the population of giant foxtail (Setaria faberii Herrm.) was occurred when allelopathic soybean-corn-wheat rotation was followed than in corn alone (Schreiber 1992). In a 5-year field study with sunflower (Helianthus annuus L.)-oat rotation, the weed density increase was significantly less in sunflower plots than in control plots (Leather, 1983 a, b; 1987). It was found that sunflower plants possess chemicals, which inhibit the growth of common weed species. Macias et al., (1999) reported some sesquiterpene lactones with germacranolide and guaianolide skeletons and heliannuol from different cultivars of sunflower.

In another study, the inclusion of alfalfa in the crop rotation sequence significantly decreased the interference of weeds in the next crops (Entz et al. 1995). Ominski et al. (1999) conducted a survey in 117 fields in Manitoba, Canada, and found that rotation with alfalfa can effectively reduce the interference of wild oat (Avena fatua L.), Canada thistle (Cirsium arvense L.), wild mustard (Brassica kaber L.) and catchweed bedstraw (Galium aparine L.) in the succeeding cereal crops. Therefore, it can be concluded that the inclusion of alfalfa in crop rotation can be an efficient tool in an integrated weed management program. However, climatic and economic conditions are important limiting factors which can notably influence the regional crop rotation scenarios.

\subsubsection{Application of allelochemicals or modified allelochemicals as herbicides}

A promising way to use allelopathy in weed control is using extracts of allelopathic plants as herbicides (Dayan, 2002; Singh et al., 2005). Because biosynthesized herbicides are easily biodegradable, they are believed to be much safer than synthesized herbicides (Rice, 1984, 1995; Dayan et al., 1999; Duke et al., 2000). Duke et al. (2000) discussed that natural compounds have several benefits over synthetic compounds. For example, natural compounds may have novel structure due to diversity of molecular structure. This diversity is because synthetic chemists have been biased toward certain types of chemistry. They have had almost no interest in water-soluble compounds. Unlike a high proportion of synthetic pesticides, natural compounds are mostly water-soluble and non-halogenated molecules. Natural products relatively have short half-life and therefore considered safe of environmental toxicology standpoint (Duke et al., 2002).

Although, allelochemicals have the potential to be explored as natural herbicides, but prior to using them as herbicides, the following questions should be considered (Bhowmik and Inderjit 2003):

1. At what minimum concentration does each compound have phytotoxic activity?

2. Whether the compound is accurately separated and correctly identified? 
3. What is the residence time and fate of the compound in the soil environment?

4. Does the compound influence microbial ecology and physicochemical properties of the soil?

5. What is the mode of action of the compound?

6. Has the compound any adverse effect on desired crops?

7. Whether the compounds are safe from health standpoint?

8. Whether the large production of the compound at commercial scale is economical?

Plant chemicals associated with allelopathic activity have been reported in most cases to be secondary metabolites from shikimic acid, acetate, or terpenoid pathways (Rizvi and Rizvi 1992; Vokou 2007). Some of the natural products exploited as commercial herbicides are triketone, cinmethylin, bialaphos, glufosinate and dicamba. The compounds having potential herbicidal activity but not commercially used are sorgoleone, artemisinin and ailanthone (Bhowmik and Inderjit 2003).

Sorgoleone is an allelochemical of sorghum which constitutes more than $80 \%$ of root exudate composition (Nimbal et al., 1996a; Czarnota et al., 2003). This compound inhibited the evolution of $\mathrm{O}_{2}$ during photosynthesis in potato (Solanum tuberosum L.) and in common groundsel (Senecio vulgaris L.) (Nimbal et al. 1996a). Nimbal et al. (1996b) carried out a study on sorgoleone using triazine-susceptible potato and redroot pigweed thylakoids. Sorgoleone was a competitive inhibitor of atrazine binding sites. Sorgoleone also inhibited the photosystem II electron transport reactions (Gonzalez et al., 1997).

However, sorghum shoots produce higher amounts of cynogenic glucosides whose phenolic breakdown products inhibit plant growth (Einhellig and Rasmussen, 1989; Weston et al., 1989; Se'ne et al., 2001). In a study, Mohammadi et al. (2009) reported that the spray of sorghum shoot extract (Sorgaab) reduced weed infestation in corn field.

Artemisinin, a sesquiterpenoid lactone is an allelochemical of annual wormwood (Artemisia annua L.). It has been shown to inhibit the growth of redroot pigweed, pitted morning glory (Ipomoea lacunosa L.), annual wormwood and common purslane (Purtulaca oleracea L.) (Duke et al., 1987). Duke et al. (1987) concluded that artemisinin is a selective phytotoxin with herbicidal activity similar to cinmethylin (Bhowmik, 1988).

Ailanthone an allelochemical of Ailanthus altissima L. exhibited a strong herbicidal activity when sprayed on soil before the seed germination. It, however, also had dramatic effects when sprayed onto seedlings after their emergence from soil (Bhowmik and Inderjit 2003).

However, most of allelochemicals indicate a poor performance under field conditions compared to laboratory conditions. Moreover, many allelochemicals exhibit rapid dissipation under natural situations and thus fail to give desired results (Singh et al. 2003). Therefore, further studies are needed to enhance performance and stability of allelochemicals under field conditions. 


\subsubsection{Modification of crops to enhance the allelopathic effect}

Breeding of crops for allelopathic ability by using the methods like screening and biotechnology is another promising strategy for efficient weed control. Just as crop plants are bred for disease resistance, crop plants can be bred to be allelopathic to weeds common to specific regions (Rice, 1984, 1995; Jensen et al., 2001; Wu et al., 2000, 2003; Olofsdotter et al., 2002; He et al., 2004). Allelopathic effect against a broad spectrum of weeds has been proposed as a valuable character of an allelopathic crop and the possibility of inserting resistance genes towards one or several weeds as part of a breeding strategy of a crop has been mentioned (Olofsdotter et al. 1997).

Genetic modification of crop plants to improve their allelopathic properties and enhancement of their weed-suppressing ability has been suggested as a possibility (Kruse et al 2000). Use of biotechnological transfer of allelopathic traits between cultivars of the same species or between species has also been proposed (Chou 1999, Macias 1995, Macias et al. 1998, Rice 1984).

Several researchers have suggested improvement of allelopathic properties of crop cultivars by traditional breeding or by genetic manipulation. For example, there has been significant progress in isolating rice allelochemicals (Rimando et al., 2001) and locating genes controlling allelopathic effects of rice (Jensen et al., 2001). These researchers identified quantitative trait loci (QTL) associated with the rice allelochemicals against barnyardgrass. This is an important step toward breeding allelopathic rice varieties. It was found that $35 \%$ of the total phenotypic variation of allelopathic activity of population was explained by four main effect QTLs situated on three chromosomes.

In wheat, the control of hydroxamic acid accumulation seems to be multigenic involving several chromosomes. Chromosomes of group 4 and 5B are apparently involved in the accumulation of hydroxamic acids (Niemeyer and Jerez 1997).

In barley, a gramine synthesis gene has been detected on chromosome 5 (Yoshida et al. 1997). Moharramipour et al. (1999) reported that one or two genes control the synthesis of gramine. DIBOA is a hydroxamic acid compound which has been found in wild Hordeum species by Barria et al. in 1992 and the production of DIBOA by cultivated barley could possibly be achieved by transferring genetic material from wild barley species (Gianoli and Niemeyer 1998).

Duke et al. (2000) suggested that biotechnology may eventually allow for the production of highly allelopathic crops through the use of transgenes to increase allelochemical production to levels that effectively manage weeds without herbicides or with reduced herbicides input. However, it has been stated by Wu et al. (1999), that even though genetic manipulation seems promising, it might be more feasible to select for crop cultivars with improved allelopathic properties using conventional breeding methods, because of the strict regulation and public concern about transgenic crops. 


\subsection{Aromatic plants}

Aromatic plants could play an important role in the establishment of sustainable agriculture because of their ability to produce essential oils that could be used in the development of biological pesticides (Isman 2000). Eessential oils are increasingly adopted in agriculture for their use as pesticides (Daferera et al. 2003; Isman 2000; Tuncw and Sahinkaya 1998).

Palmer amaranth (Amaranthus palmeri L.) germination was inhibited by essential oils of certain aromatic plants including lemon basil (Ocimum citriodorum L.), oregano (Origanum vulgare L.), and sweet marjoram (Origanum majorana L.) (Dudai et al. 1999). Dhima et al. (2009) found that anise, sweet fennel, lacy phacelia, and coriander aqueous extracts inhibited by $100 \%$ germination, root length, and seedling fresh weight of barnyardgrass. In another study, Tworkoski (2002) tested 25 plant-derived essential oils for herbicidal activity and found that those from red thyme (Thymus vulgaris L.), summer savory (Satureja hortensis L.), cinnamon (Cinnamomum zeylanicum L.) and clove (Syzygium aromaticum L.) were most toxic and caused cell death due to rapid electrolyte leakage on the detached leaves of dandelion (Taraxacum officinale L.).

\section{Cover crops and living mulches}

The term cover crop refers to a plant which is grown in rotation during periods when main crops are not grown. Cover crops are usually killed (mechanically or chemically) before the planting of the main crop. However, living mulches are cover crops that are planted between the rows of a main crop and are maintained as a living ground cover during the growing season of the main crop. Although, living mulches are sometimes referred to as cover crops, they grow at least part of the time simultaneously with the main crop. Apart from the definitions, both cover crop and living mulch suppress weeds by the similar mechanisms.

In general, cover cropping systems have high potentials for weed management in agroecosystems. Cover cropping has long and short-term weed control effects (Barberi 2002) as a result of competition and/or allelopathy exerted by the crop (Randall et al. 1989; Boydston and Hang 1995). These effects can enhance the effectiveness of other non-chemical weed control means in view of an effective integrated approach (Creamer et al. 1996; Bond and Grundy 2001). Long-term weed control effects are due to the prevention of emergence and/or seedling suppression of species of different seasonality compared to the following crop, while short-term effects take place when emergence prevention and seedling suppression occur in species presenting the same seasonality of the following crop (Campiglia et al. 2009).

\subsection{How can a cover crop or living mulch affect weed growth?}

The effects of a cover crop or living mulch are achieved by a rapid occupation of the open space between the rows of the main crop or generally, the niches that would normally be filled by weeds (Teasdale 1998). This prevents germination of weed seeds and reduces the 
growth and development of weed seedlings. Generally, the weed suppressing ability of these systems is thought to be based on alleopathic properties, physical impedance of germination and seedling growth, and competition for light, water, and nutrients (Teasdale, 1993; Teasdale and Mohler, 1993).

Germination of weed seeds may be inhibited by complete light interception (Phatak, 1992) by cover crops or by secretion of allelochemicals (White et al., 1989; Overland, 1966). A delay in emergence of weeds because of the presence of living mulches or cover crops can also adversely affect weed seed production. Moreover, the presence of living mulches or cover crops leads to greater seed mortality of weeds by favoring predators (Cromar et al. 1999).

Once established, cover crops and living mulches can use the light, water, and nutritional resources that would otherwise be available to weeds. This can result in the inhibition of weed seed germination and reduction in the growth and development of weed seedlings. Therefore, weeds attempting to establish along with a cover crop or living mulch would be in competition for resources and may not develop sufficiently. Moreover, physical impediment to weed seedlings is another mechanism by which these crops suppress weeds (Facelli and Pickett 1991; Teasdale 1996; Teasdale and Mohler 1993).

Since, most crop-living mulch systems are sufficiently supported by water and nutrients, it seems that light is the most important resource for competition between living mulches and weeds. In a study, Kruidhof et al. (2008) found that weed suppression is positively correlated to early light interception by the living mulch and is sustained by the strong negative correlation between cumulative light interception and weed biomass. Similarly, Steinmaus et al. (2008) reported that weed suppression was linked to light interception by the mulch cover for most weed species.

Allelopathy is another mechanism by which living mulches may suppress weeds (Fujii 1999). However, this is difficult to separate experimentally from mechanisms relating to competition for growth resources. Allelopathic compounds can be released into the soil by a variety of mechanisms that include decomposition of residues, root exudation, and volatilization (Weston 2005). According to Westra (2010) root exudation produces allelopathic compounds that are actively secreted directly into the soil rhizosphere by living root systems. The allelochemicals then move through the soil by diffusion and come into contact neighboring plants. This creates a radius effect, where proximity to the allelopathic species results in greater concentrations of the allelochemical, which, in turn, typically decreases the growth of neighboring plants.

\subsection{Factors influencing the weed suppressive ability of a cover cropping system}

The success of a cover cropping system to suppress weeds can be influenced by some factors including:

\subsubsection{Cover crop species}

The variability among cover crop species determines the importance and opportunities of species selection as a component in the design of a suitable weed management system (den 
Hollander et al. 2007). Cover crop species are significantly different in their ability to suppress weeds. In a study, among six leguminous species (Persian clover, Trifolium resupinatum L.; white clover, T. repens L.; berseem clover, T. alexandrinum L.; hairy vetch; alfalfa; and black alfalfa, M. lupulina L.), the lowest weed dry weights were obtained from the plots interseeded with hairy vetch as compared with the other species (Mohammadi 2009).

Morphological growth characteristics, such as early relative growth rate of leaf area and earliness of height development, have been identified to determine competition in intercropping systems (Kropff and van Laar 1993). Weed suppression benefits from a rapid soil cover, as this reduces the germination and establishment of weeds as well as the relative competitive ability of established weed seedlings (Ross and Lembi, 1985). The relative growth rate reflects the increase of characteristics like soil cover and dry matter accumulation during early development, when growth is still exponential. The relative growth rate of a plant species is thus affected by its light capturing ability, by the efficiency by which it converts light into biomass and by the fraction of newly produced biomass which is invested in leaves (den Hollander et al. 2007).

For weed competition and weed suppression, earliness has also been reported an important characteristic (De Haan et al., 1994). Particularly for competition for light, which is asymmetric (Weiner, 1986), obtaining a good starting position seems highly relevant. From that perspective the relative growth rate seems to be a more important characteristic than the maximum accumulated amount of biomass (den Hollander et al. 2007).

Apart from soil cover development, height is also an important characteristic, determining competition for light (Berkowitz, 1988). Akanvou et al. (2001) found that Crotalaria juncea, Cajanus cajan and M. pruriens can be considered as species with a higher competitive ability than Calopogonium mucunoides, Stylosanthes hamata and A. histrix. This was explained by the combination of high initial growth rates for height and leaf area development. Additionally, the high final height of $C$. juncea and C. cajan may confer higher competitiveness throughout the growing season.

However, differences in soil cover development do not only depend on species differences in morphology and physiology. The relative starting position, determined by, for instance, seed size, seeding rate and date of emergence, is another major factor in this respect. As small-seeded species may be more sensitive to conditions that might cause a poor establishment (den Hollander et al. 2007).

In general, ideal cover crops or living mulches for weed suppression should have the following characteristics:

a. Ability to provide a complete ground cover of dense vegetation.

b. Rapid establishment and growth that develops a canopy faster than weeds.

c. Selectivity between suppression of weeds and the associated crop (Teasdale 2003). 


\subsubsection{Agricultural practices}

Among agricultural practices, both time and rate of living mulch or cover crop planting can be important factors determining the success of a these systems to suppress weeds. In a study, Mohammadi (2010) observed that increased hairy vetch planting rate from 0 to $50 \mathrm{~kg}$ ha $^{-1}$ improved corn yield (by 11\%) and reduced weed dry weight (by 50.9\%). In another study, increasing berseem clover (as a living mulch) planting rate from 20 to $40 \mathrm{~kg} \mathrm{ha}^{-1}$ reduced weed density and biomass by 20.2 and 10.1\% respectively, in corn field (Mohammadi et al. 2012). It was hypothesized that as living mulch density is increased, canopy closure would occur more rapidly, decreasing the amount of photosynthetically active radiation (PAR) available beneath the canopy. This would result in a concomitant decrease in weed biomass until an optimum living mulch density is achieved, beyond which, no further decrease in weed biomass could be obtained (Collins et al. 2008).

Planting time of a cover crop or living mulch is also a very important factor which affects its weed suppressive ability. For example, when rye (Secale sp.) or small-grain living mulches were interseeded at or near planting of the main crop, they could provide higher levels of weed suppression (Rajalahti et al. 1999; Brainard and Bellinder 2004). Mohammadi et al. (2012) also reported that the lowest weed density and biomass were occurred in the treatment in which berseem clover (as a living mulch) was interseeded 15 days before corn planting as compared with the other interseeding times (simultaneous with or 15 days after corn planting). This may be related to the faster occupation of the open space between the rows of the main crop and consequently a more efficient use of the environmental resources by the living mulch which can ultimately lead to the reduced weed growth and development.

Generally, the biomass produced by a living mulch highly depends on its planting rate and time. Moreover, there is often a negative correlation between living mulch and weed biomasses (Akemo et al. 2000; Ross et al. 2001; Sheaffer et al. 2002). Similar findings were also reported by other researchers (Meschede et al. 2007; Mohammadi 2010; Mohammadi et al. 2012).

However, an important concern on cover cropping systems is reduced main crop yield due to competition or allelopathic effects of living mulches or cover crops. Therefore, appropriate management of these systems is very critical to reduce harmful effects of cover crops or living mulches on main crop while allowing them to grow sufficiently to reap potential benefits. The selection of suitable cover crop and living mulch species is very important. Ideally, the main crop and the cover crop should differ to a high degree in the way they explore resources, thus avoiding competition between both species to at least some extent (Vandermeer, 1989). Generally, greater potential benefits might be expected from living mulches with a very different active growth period than the main crop.

Other attempts have also been made to reduce the unsuitable effects of the cover crops while maintaining their weed suppressing ability. Brandsaeter and Netland (1999) focused on temporal complementarity by separating periods of vigorous growth of the cover crop and the main crop, while Vrabel (1983) used chemical control of the cover crop to reduce yield losses. Brainard et al. (2004) evaluated different options, particularly, cover crop spe- 
cies, time of seeding, use of supplemental nitrogen and herbicide regulation. Ross et al. (2001) conducted mechanical control of the cover crop and combined this with a screening of different cover crops.

It can be concluded that, although, inclusion of cover crops and living mulches in cropping systems can be useful to reduce harmful effects of weeds, but an appropriate management program is very essential to obtain the best results.

(For more information on the weed suppressing role of living mulches and their management in cropping systems, please see Mohammadi (2012), Living mulch as a tool to control weeds in agroecosystems: A Review).

\section{Planting arrangement}

An integrated weed management approach should employ multiple control strategies (Walker and Buchanan 1982), possibly including the development of weed suppressing cropping systems (Shrestha and Fidelibus 2005). Alteration of planting arrangement can be proposed as an efficient practice to suppress weeds in agroecosystems. This can be achieved by the change of planting density, row spacing, row orientation, etc.

\subsection{Planting density and row spacing}

The practice of increasing crop plant density by using higher seeding rates associated with narrower row spacing can lead to earlier canopy closure, thus shading weeds in their early developmental stages (Vera et al. 2006). Sharma and Angiras (1996 a,b) and Angiras and Sharma (1996) found that reduced row spacing increased light interception by crops and reduced weed biomass, increasing crop yield. The studies conducted on barley (Hordeum vulgare L.) have shown that higher seeding rates using cultivars with differing competitive abilities enhanced crop competitiveness against wild oat (Avena fatua L.) (Harker et al. 2009; Watson et al. 2006; O'Donovan et al. 2000).

In general, increasing crop seeding rates can hasten and increase resource use, and thereby reduce the negative effect of weeds (Berkowitz 1988; Mohler 1996). Therefore, weed management and cereal and pulse crop yields were improved with higher than recommended seeding rates in the absence of herbicides (Barton et al. 1992; Kirkland 1993; Townley-Smith and Wright 1994; Khan et al. 1996; Ball et al. 1997; O’Donovan et al. 2000). In another study, tartary buckwheat (Fagopyrum tataricum) was effectively suppressed when canola (B. rapa) seeding rate was increased from 2 to $8 \mathrm{~kg} \mathrm{ha}^{-1}$ (O'Donovan and Newman 1996).

Weed suppression by crops appears to be enhanced by size-asymmetric competition, in which the larger crop plants suppress the initially smaller weed plants (Schwinning and Weiner 1998; Weiner 1990). At high-density, size-asymmetric competition is stronger and starts earlier, whereas the crop still has a large size advantage. At relatively low crop densities, crop cover early in growing season is low, leaving a larger amount of resources available for the weeds, thus enabling them to establish and grow quickly (Kristensen et al. 2008). 
Row spacing can also affect the crop competitive ability against weeds. In a study, rice grown in 30-cm rows had greater weed biomass and less grain yield than in $15-\mathrm{cm}$ and 10 $20-10-\mathrm{cm}$ rows and crops in the wider spacing $(30-\mathrm{cm})$ were vulnerable to weed competition for the longest period (Chauhan and Johnson 2011). In another study, Mohammadi et al. (2012) reported that corn yield improved and weed biomass reduced in response to increasing plant density and decreasing row spacing.

Row spacing can also influence the critical period of weed control in crops. It is hypothesized that narrow row spacings may decrease the interval of critical weed competition periods (Chauhan and Johnson 2011). According to Chauhan and Johnson (2011) the critical weed-free periods for rice planted at the $30-\mathrm{cm}$ rows were up to 8 days longer than the other two rows spacings (15-cm and 10-20-10-cm rows).

Moreover, several studies have documented the reduced competitive ability of short-stature cultivars (Harker et al., 2009; O'Donovan et al., 2000) and improvements in the competitive ability of shorter varieties could be derived from narrower row spacing (Drews et al., 2004).

In general, the higher weed densities typical in low-input and organic systems may make narrow row spacing and higher planting density particularly attractive.

\subsection{Row orientation}

Light is an important determinant of crop productivity. Crops can be manipulated to increase shading of weeds by the crop canopy, to suppress weed growth, and to maximize crop yield (Borger et al. 2010). In general, cropping systems that reduce the quantity and quality of light in the weed canopy zone suppress weed growth and reduce competition (Borger et al. 2010; Crotser and Witt 2000; Rajcan et al. 2002; Sattin et al. 1994; Shrestha and Fidelibus 2005; Teasdale 1995). During early growth stages, there is interference between crop and weed plants because of reflected light. The reflection of far-red photons by the stem of one plant lowers the red to far red photon ratio of light experienced by the stems of neighboring plants. This modifies the light environment in the plant stem tissue, which results in an increased stem elongation rate. As plants age, the crop canopy closes, and mutual shading further increases the competition for photosynthetic light (Borger et al. 2010).

One possible way to reduce light interception by weeds and to increase light interception by the crop canopy is to manipulate the crop row orientation (Holt 1995). So that, orientating crop rows at a near right angle to the sunlight direction increases the shading of weeds between the rows. In a study, within wheat and barley crops oriented east-west, weed biomass was reduced by 51 and 37\%, and grain yield increased by 24 and $26 \%$ (compared with crops oriented north-south). This reduction in weed biomass and increase in crop yield likely resulted from the increased light (photosynthetically active radiation) interception by crops oriented east-west (i.e., light interception by the crop canopy as opposed to the weed canopy was 28 and $18 \%$ greater in wheat and barley crops oriented east-west, compared with north-south crops) (Borger et al. 2010).

According to Alcorta et al. (2011), rows oriented east-west allowed less light penetration to the weed canopy zone than north-south rows throughout the growing season and weed spe- 
cies responded to low light levels by producing leaves with larger specific leaf area and leaf area ratios than those in the north-south rows. Moreover, the leaf, stem and root dry weight of the weed species in the east-west rows was reduced by $30 \%$ compared to the weed species in north-south rows.

According to the results of another study, during periods of peak PAR, the Red : Far Red $(\mathrm{R}: \mathrm{FR})$ ratio was more than three times greater under the grape canopy in north-south rows than in east-west rows, indicating that row orientation can affect both quantity and quality of light available to weeds (Shrestha and Fidelibus 2005).

However, the effect of row orientation can vary with latitude and with the seasonal tilt of the earth in relation to the sun. Near the equator, north-south (as opposed to east-west) orientation gives crops higher levels of light absorption for most of the year. At higher latitudes (up to $55^{\circ}$ ), absorption is highest in north-south crops in summer and east-west crops for the rest of the year. From $65^{\circ}$ upwards, east-west orientation gives greatest light absorption all year (although the difference between orientations is minor) (Mutsaers 1980).

It can be concluded that manipulation of row orientation can be an ideal method to incorporate into an integrated weed-management program because it does not cost growers anything to implement, and it is environmentally friendly compared with chemical weed control tactics (Mohler 2001). However, the geographical and seasonal conditions should be considered.

\subsection{Spatial uniformity}

According to Kristensen et al. (2008) increased crop density and spatial uniformity can play an important role in weed management and a strategy based on increased crop density and spatial uniformity can reduce or eliminate herbicide application in conventional cereal production. Crop spatial uniformity decreases competition within the crop population early in the growing season (Olsen and Weiner 2007) and maximizes the total shade cast by the crop by reducing self-shading (Weiner et al. 2001). In a study, In the presence of weeds, the highest yields were obtained with high crop density and high spatial uniformity (Kristensen et al. 2008).

However, the early size advantage of the crop is the theoretical basis for our prediction of positive effects of increased density and spatial uniformity on weed suppression (Weiner et al. 2001). Therefore, it can be concluded that increased crop density and uniformity will not lead to effective weed suppression when weeds have the initial size advantage (e.g., perennial weeds), or are able to catch up in size with the crop before competition becomes intense (Kristensen et al. 2008). Moreover, one might expect the effects of high crop density and spatial uniformity on weeds to be more pronounced at low soil nitrogen levels because weeds grow more slowly at low fertilization levels (Blackshaw et al. 2003). 


\section{Competitive crop cultivars}

In a plant community, competition occurs when the environmental resources are limited. Competition for limited resources is the primary causes of crop loss from weeds. Crop cultivars that better compete with weeds or preempt resources from weeds may benefit an integrated weed management program (Jordan 1993; Lemerle et al. 1996; Lindquist and Kropff 1996).

The competitive ability of a plant has two components, the competitive effect-ability of an individual to suppress other individuals - and the competitive response-ability of an individual to avoid being suppressed-corresponding to different abilities of plants to acquire and use resources (Goldberg, 1990). Competitive effect is related to resource acquisition, with large or tall plants competitively depressing smaller ones (Gaudet and Keddy, 1988; Keddy and Shipley, 1989; Aarssen, 1992). Plants avoid being suppressed by acquiring resources faster (foraging strategy), shifting resource acquisition site or time relative to neighbors (escaping strategy), or conserving scarce resources (persistent strategy) (Navas and Moreau-Richard 2005).

The development of competitive crop cultivars is an important aspect of integrated weed management and can reduce reliance on herbicides (McDonald 2003). The ideal weed competitive cultivars are high-yielding under both weed-free and weedy conditions and have strong weed-suppressive ability. Weed-suppressive ability is the ability to suppress weed growth and reduce weed seed production and, hence, benefit weed management in the subsequent growing season (Jannink et al., 2000; Zhao et al., 2006).

In a general view, crop competitive ability can be divided into two practical perspectives. Crop tolerance is defined as the ability of the crop to endure competitive stress from the presence of weeds without substantial reduction in growth or yield. Weed suppressive ability is the ability of the crop to reduce weed growth and fecundity (So et al. 2009). Weed suppressive ability is determined by assessing weed biomass or weed seeds under weedy conditions. Stronger Weed suppressive ability is not always associated with higher yield under weedy conditions (Saito et al. 2010). However, suppressing weeds reduces weed seed production and benefits weed management in future grow- treating seasons while tolerating weeds only benefits the current growing season. Moreover, weed pressure from unsuppressed weeds increases the likelihood of crop yield loss, irrespective of the crop's tolerance (Jannink et al. 2000).

Ideally, a competitive cultivar should both tolerate weeds and suppress their growth (Jordan 1993). The tolerance of a crop cultivar to weeds is the ability of that cultivar to maintain high seed yields when weeds are present. The weed suppression ability of a crop cultivar is the ability of that cultivar to reduce weed growth and subsequent seed production (Spies et al. 2011). Callaway (1992) documents genetic variability for both perspectives in numerous crop species and many authors suggest breeding to improve the traits (Garrity et al., 1992; Callaway and Forcella, 1993; Kropff and van Laar, 1993; Wortmann, 1993; Liebman and Gallandt, 1997; Bussan et al., 1997). 
In general, the traits offering weed competitive ability to crop cultivars can be divided into the several groups including:

\subsection{Canopy and morphological traits}

Canopy architecture influences many canopy processes including interactions between the crop and specific aspects of its environment (Daughtry et al., 1983; Welles and Norman, 1991). Canopy architecture is a function of leaf number, shape, distribution, orientation, and plant size, which collectively determine the vertical distribution of light within the crop canopy (Williams et al., 1968; Girardin and Tollenaar, 1994).

Sinoquet and Caldwell (1995) reported that light is the primary resource for which weeds will compete in an irrigated and high $\mathrm{N}$-input crop production system. Total canopy leaf area index, height, rate of leaf area development and their distribution in the canopy, are the most important traits in competition for light (Sinoquet and Caldwell, 1995), which can be improved through cultural practices or/and by plant breeding (Lindquist and Mortensen, 1998). Identifications and improvements in traits driving light interception, such as height, leaf area index and canopy diameter can increase competitiveness of several crops (Bennett and Shaw 2000; Callaway 1992; Lindquist and Mortensen 1998; Lindquist et al. 1998). According to Watson et al. (2002) a species competitive strength is strongly determined by its share in leaf area when the canopy closes and interplant competition starts. In general, rapid canopy closure and a large, late-maturing canopy were positively associated with competitive ability (So et al. 2009).

In field pea cultivars, vine length and the leafy characteristic may be important genetic characteristics associated with competition (Spies et al. 2011). However, Wall and TownleySmith (1996) believed that vine length was more important than the leafed or semi leafless trait. Several traits relate to competitive ability of dent corn, including plant height, shoot growth rate, canopy density (Lindquist and Mortensen 1998), leaf uprightness (Sankula et al. 2004), crop maturity, leaf area growth rate (Begna et al. 2001 a, b), canopy closure, and maximum leaf area index (Lindquist et al. 1998).

In an experiment, when wild-proso millet competed with sweet corn, hybrids with a large canopy were best equipped to tolerate the weed and suppress wild-proso millet growth and seed production, even for late-maturing hybrids that competed the longest period of time (So et al. 2009).

Plant height and tillering ability are also key characteristics for wed suppressive ability under specific growing environments. Their relative contributions to weed suppressive ability could be affected by crop establishment method, agro-ecosystems (upland or lowland) or weed species (Saito et al. 2010). According to Lemerle et al., (1996) greater tiller numbers, taller plants, elevated photosynthetically active radiation interception, and greater early season biomass accumulation were all found in the most competitive genotypes in a study of wheat genotypes from around the world.

Wang et al. (2006) also reported that an erect cowpea genotype is more competitive due to its taller stature, greater height growth rate, and higher position of maximal leaf area densi- 
ty, despite a lower photosynthetic rate and light use efficiency than the other cowpea genotypes. They concluded that erect growth habit may be generally more competitive with weeds compared to semi-erect or prostrate growth habit. In another study, the size of the flag leaf has been correlated with competitive ability in barley (Watson et al. 2002).

\subsection{Phenological traits}

Weed species differ markedly in their development phenologies. An effective, 'broad spectrum' weed-suppressive cultivar will therefore need a strong competitive presence over the full duration of the season. The positive correlation between weed biomass and time to maturity of cultivars in organic fields indicates that weed growth was higher in cultivars with increased time to maturity. Thus, it may be desirable for organic producers to use early maturing cultivars to reduce weed biomass in the field (Jannink et al. 2001). In other words, faster time to maturity was found to be associated with reduced weed biomass. Huel and Hucl (1996) in evaluating 16 genotypes of spring wheat (Triticum aestivum L.), found a positive correlation between early maturity and competitive ability. In another study, earlier flowering cultivars of soybean were more successful at suppressing weed growth.

In general, earlier maturing cultivars might have higher relative growth rate. Across a broad spectrum of species, researchers have found a negative relationship between leaf longevity and plant relative growth rate (Reich et al., 1997). They posit that this relationship occurs because long-lived leaves require more structural carbon and protective secondary metabolites than short-lived leaves, such that the cost to the plant of developing photosynthetic capacity is greater (Jannink et al. 2001).

Moreover, earlier maturing cultivars might produce larger seeds if they diverted a greater proportion of photosynthate to their fewer reproductive structures (Kollman et al., 1979; Openshaw et al., 1979; Wallace et al., 1993). With a larger initial size they might achieve a higher absolute growth rate despite equal relative growth rate. This can lead to the higher competitive abilities of these cultivars.

However, this idea contrasts with that of some workers who have suggested that later maturity confers greater competitive ability against weeds because cultivars that remain vegetative grow to be taller (Hinson and Hanson, 1962; McWhorter and Hartwig, 1972; Monks and Oliver, 1988). Jannink et al. (2000) also found earlier-maturity soybean cultivars displayed greater initial growth and weed suppression, compared to later-maturity cultivars, but were less able to sustain weed suppression throughout the season due to senescence. It can be concluded that earlier maturing cultivars have a higher weed suppressive ability if they can sustain this ability throughout the growing season.

\subsection{Growth parameters}

In plant ecology, relative growth rate (RGR) is considered to be one of the key characteristics of plants that is positively correlated with competitive ability (Grime 1977; Grace 1990). Holt and Ocrutt (1991) showed that the RGR is one of the most important plant growth parameters to increase the competitive ability of cotton against weeds. As a result of a high RGR, a 
crop will rapidly increase in size and can occupy a larger space, both below and above ground. Consequently, such a crop has the opportunity to acquire a larger share of limiting resources, such as light, nutrients, and water, than a weed.

In a study conducted by Mohammadi (2007) some plant growth parameters including leaf area index, specific leaf area, crop growth rate, relative growth rate and net assimilation rate were evaluated to identify which of them can enhance corn competitive ability against weeds. The variable selection using the stepwise multiple linear regression method revealed that, among the growth parameters under study, both the relative growth rate and the specific leaf area (SLA) were the best predictors of corn cultivar competitiveness.

Broad surveys across taxa have found SLA to predict relative growth rate (Hunt and Cornelissen, 1997; Reich et al., 1997) and implicate SLA in competitive ability (van der Werf et al., 1993). A high SLA contributed to increased light interception by crops ( Jannink et al. 2000) and led to a reduction in the amount of light available to weeds. According to Johnson et al. (1998), a high SLA is one of the best predictors of cultivar competitiveness against weeds. Dingkuhn et al. (1999) also reported that more weed competitive cultivars have a high SLA, which leads to a high leaf area index.

Tollenaar et al. (1994) showed that differences among corn hybrids in competition against weeds can be attributed to differences among them in the leaf area index and the transmission of late-season photosynthetic photon flux density. In the case of interactions with weeds, more rapid early leaf area development, higher leaf area index and biomass accumulation can play important roles. Leaf area and plant height might affect significantly cropweed interactions (Blackshaw, 1994; Lemerle et al., 1996). Cultivars with strong weed suppressive ability accumulated more biomass, produced more tillers and displayed higher leaf area index during the vegetative growth stage than those with weak weed suppressive ability (Saito et al. 2010).

Plant height is another growth parameter which can influence weed suppressive ability of a crop cultivar. The negative correlation between weed biomass and plant height in organic fields implies that weed biomass decreased as height increased, suggesting that height does help to suppress weeds. In several studies, plant height was associated with competitive ability in both conventional (Huel and Hucl, 1996; Lemerle et al., 1996; Hucl, 1998) and organic systems (Gooding et al., 1993). In soybean, plant height 6 to $7 \mathrm{wk}$ after emergence showed moderately high heritability, strong genetic correlation to weed suppressive ability and was quick and simple to measure. These characteristics make it an ideal indirect selection criterion, particularly in a practical soybean breeding program where labor needs at the time to measure early height are not as high as in the spring or the fall (Jannink et al. 2000).

In rice, under severe weed competition, higher biomass accumulation at 42 days after sowing was associated with higher weedy yield. For adaptation to both moderate and severe weed pressure, cultivars should have high-yielding ability, high plant height at maturity, and large biomass accumulation at 42 days after sowing (Saito et al. 2010). Dingkuhn et al. (1999) also considered relative yield (the ratio of grain yield under weedy conditions and grain yield under weed-free conditions) as an indicator of weed competitiveness and Roden- 
burg et al. (2009) showed that longer duration and higher yield under weed-free conditions were associated with higher grain yields under weedy conditions.

\subsection{Seed traits}

In annual plants, and thus in many agricultural contexts, seed size can be an important determinant of success during initial stages of competition simply because larger seeds lead to greater initial growth and therefore to greater capture of available resources at the expense of other competitors (Black, 1958; Ross and Harper, 1972). Vigorous seed, expressed as early emergence and root growth contribute to cultivar competitiveness against weeds. In sweet corn, early vigor and seedling growth rate are largely attributed to endosperm phenotype, specifically, the result of starch concentration of the endosperm (Azanza et al. 1996).

In general, seed vigour within a genotype has been attributed to seed size, protein, which is in turn related to ATP production and ultimately, mitochondrial quality and quantity. Seed vigour has been positively related to both seedling vigour and final yield and can be improved to enhance crop competitive ability (Watson et al. 2002).

\section{Nutrient management}

A suitable nutrient management program can be an effective tool to control weeds in cropping systems. The competitive relationship between crop and weeds is highly dependent on supply and availability of nutrients (Evans et al. 2003; Di Tomaso 1995). Manipulation of soil fertility, whether using organic or inorganic amendments should be considered as an important component of long-term weed management programs and effective fertilizer management is an important component of integrated weed management systems (Blackshaw et al. 2007; DiTomaso 1995). Unfortunately, nutrients applied to soils are also available for weeds. In most farming systems, competition for $\mathrm{N}$ is the most important source of nutrient interference (DiTomaso 1995). Walker and Buchanan (1982) also found that of all nutrients, plant response to nitrogen $(\mathrm{N})$ fertilizer is the most widely observed and the manipulation of soil $\mathrm{N}$ supply offers the most promise in the short term as a means by which crop-weed competitive outcomes can be influenced.

Therefore, it is important to develop fertilization strategies for crop production that enhance the competitive ability of the crop, minimize weed competition, and reduce the risk of nonpoint source pollution from nitrogen (Cathcart and Swanton 2003; DiTomaso 1995).

\subsection{Aspects of nutrient management}

Different aspects of nutrient management including fertilizer rate, timing and application method can be successfully manipulated to reduce weed interference in crops (Angonin et al. 1996; Blackshaw et al. 2004; Van Delden et al. 2002). 


\subsubsection{Application rate and timing}

Weed emergence and growth in the field can be stimulated by fertilizer application rate and timing. Generally, weed growth may increase as the nitrogen application rate increases, resulting in the need for more frequent POST herbicide applications or cultivation (Sweeney et al. 2008). In sugar beet, weed emergence from sown seed increased as the $\mathrm{N}$ application rate at planting increased from 56 to $224 \mathrm{~kg} \mathrm{~N} \mathrm{ha}^{-1}$ (Dotzenko et al. 1969).

The timing of fertilizer application in early planted crops, such as sugar beet and corn, may especially influence the germination, emergence, and competitiveness of weeds that might otherwise remain dormant early in the growing season. In a study, when nitrogen was broadcasted in April at the time of planting, weed germination and emergence were stimulated. In contrast, nitrogen application at the time of planting in May did not influence seed germination and weed emergence because of greater $\mathrm{N}$ availability because of mineralization at this time of year or because seed germination has been stimulated by other environmental cues (Sweeney et al. 2008). Results of both greenhouse (Alka"mper et al. 1979) and field experiments (Davis and Liebman 2001; Dyck et al. 1995) indicate that for certain crop-weed combinations, delaying soil $\mathrm{N}$ availability can shift the competitive balance to favor crop growth. For example, the competitiveness of wild mustard (Sinapis arvensis L.), a winter annual, in sugar beet was favored by early compared with late nitrogen fertilization (Paolini et al. 1999). Generally, delaying nitrogen applications, applying slow-release nitrogen fertilizers or placing nitrogen below the weed seed germination zone could be potential strategies for reducing early season weed establishment in cropping systems (Sweeney et al. 2008).

In the case of phosphorus, early-season application is critically important for vigorous plant growth and development (Grant et al. 2001). Thus, fertilization strategies that restrict weed access to phosphorus fertilizer early in the growing season would appear to have merit (Blackshaw and Molnar 2009).

\subsubsection{Application method}

Crop-weed interactions can also influence by fertilizer application method. Since, weeds often germinate at or near the soil surface, especially in zero-tillage systems (Yenish et al., 1992; Hoffman et al., 1998), therefore, in this situation the greatest benefits may be realized by physically placing nitrogen $(\mathrm{N})$ in an area of the soil profile where crop seeds, but not weed seeds, are germinating (Blackshaw 2005). Subsurface-banded $\mathrm{N}$ was often better than surface-broadcast $\mathrm{N}$ fertilizer in terms of $\mathrm{N}$ uptake by wheat vs. weeds, weed biomass production and wheat yield (Blackshaw et al. 2005).

Petersen (2003) reported that weed N uptake and weed biomass were 50\% lower with subsurface-banded compared with surface-broadcast liquid swine manure. Rasmussen (2002) similarly documented lower weed biomass and higher crop yield with injected than with surface-broadcast liquid swine manure. In another study, subsurface-banded $\mathrm{N}$ compared with broadcast $\mathrm{N}$ fertilizer reduces $\mathrm{N}$ uptake by weeds and decreases weed growth and bio- 
mass. Moreover, banded $\mathrm{N}$ fertilizer resulted in the lowest seed bank numbers of both grass and broadleaf weeds (Blackshaw 2005).

Phosphorus $(\mathrm{P})$ fertilization practices could also have an impact on the extent of interference by weeds. Researchers indicated that banding P near lettuce rooting system as opposed to broadcast $\mathrm{P}$ could potentially reduce the damage of spiny amaranth (Amaranthus spinosus), smooth pigweed, and common purslane by enhancing the competitive ability of the crop (Santos et al. 1997; Shrefler et al. 1994). In wheat, seed-placed or mid row-banded P compared with surface-broadcast $P$ fertilizer often resulted in higher yields when wheat was in the presence of competitive weeds (Blackshaw and Molnar 2009).

In general, weed P concentration and biomass production were often greatest with surfacebroadcast $\mathrm{P}$ fertilizer, indicating that this common application method of $\mathrm{P}$ fertilizer should be discouraged. Alternative practices such as seed-placed or subsurface-banded P fertilizer were less advantageous to weeds. Weed seed bank was also affected by P application method. So that, seedbank evaluation at the end of the experiment indicated that the seed density of five of six weed species under study was reduced with seed-placed or subsurface-banded P compared with surface-broadcast P (Blackshaw and Molnar 2009).

However, the benefit of seed-placed or subsurface-banded P fertilizer will likely be greatest in soils with low background P levels and within zero-tillage production systems, where weed seeds are not distributed throughout the soil profile but rather concentrated near the soil surface (Blackshaw and Molnar 2009).

\subsection{Organic and biofertilizer}

Organic manure may affect crop-weed competitive interactions differently than chemical nitrogen fertilizer (Davis and Liebman, 2001), probably due to speed of $\mathrm{N}$ release or form of $\mathrm{N}$. In a study, the gradual $\mathrm{N}$ release from manure and compost over years appeared to benefit weeds more than spring wheat. Moreover, fresh and composted manure had the greatest seed bank of both grass and broadleaf species as compared with chemical fertilizer treatment (Blackshaw 2005). In another study, Mohammadi et al. (2012) found that phosphate biofertilizer had no significant effect on corn yield, whereas, weed biomass was notably increased when phosphate biofertilizer was applied.

It seems that, in most cases, weed infestation level and duration may enhance by the use of organic fertilizers. However, the other beneficial aspects of these fertilizers should not be ignored.

\subsection{Critical period of weed control in response to nutrient management}

The critical period of weed control (CPWC) is an important principal of an integrated weed management program. It is a period in the crop growth cycle during which weeds must be controlled to prevent yield losses (Knezevic et al. 2002). Weeds that are present before or emerge after this period do not cause significant yield loss. Studies on the critical period of weed control are important in making weed control recommendations because they indicate 
the optimum time for implementing and maintaining weed control and reduce cost of weed control practices (Hall et al. 1992; Van Acker et al. 1993).

According to Weaver et al. (1992) the manipulation of edaphic factors including the alteration of soil nutrient supply can influence the crop-weed interference relationships, especially in determining the critical time of weed removal (the start of the critical period). Evans et al. (2003) reported that the addition of nitrogen fertilizer delayed the beginning and hastened the end of the critical period of weed control in corn. Their study showed that the effect of nitrogen fertilization on early season crop growth provided a competitive advantage for corn relative to weeds. In another study, Mohammadi and Amiri (2011) found that the use of mono ammonium phosphate as a starter fertilizer slightly delayed the end of the CPWC in soybean (by 5 days), but this condition shortened the CPWC by 12 days because of the later beginning of the CPWC (by 17 days).

\subsection{Weed response to fertilization}

Some weed species are considered to be luxury consumers of nutrients (Qasem 1992; Teyker et al. 1991) and this might contribute to their ability to take up higher amounts of $\mathrm{N}$ at higher $\mathrm{N}$ fertilizer rates. Weeds not only reduce the amount of $\mathrm{N}$ available to crops but the growth of many weed species is enhanced by higher soil N levels (Blackshaw et al. 2003; Henson and Jordan 1982; Supasilapa et al. 1992). Thus, adding N fertilizer in cropping systems can potentially have the unintended consequence of increasing the growth and competitive ability of weeds more than that of the crop.

In a greenhouse study, Teyker et al. (1991) reported greater $\mathrm{N}$ uptake for redroot pigweed (Amaranthus retroflexus L.) than corn when the addition of $\mathrm{N}$ was elevated, suggesting that redroot pigweed interference in corn may be greater at higher levels of N. Others also have postulated that weeds may be more competitive when fertility is enhanced with $\mathrm{N}$ addition because of the superior uptake efficiency of many weed species (Di Tomaso 1995; Sibuga and Bandeen 1980).

At the conclusion of a 47-yr soil fertility study, carpetweed (Mollugo verticillata L.) and henbit (Lamium amplexicaule L.) densities were greatest on plots that had received annual applications of P fertilizer (Banks et al. 1976). In another study, downy brome (Bromus tectorum L.) densities were reported to be higher on soils with higher P levels (Belnap et al. 2003). Verma et al. (1999) similarly reported that weed growth and competitiveness with fenugreek (Trigonella foenum-graecum L.) increased at the higher soil P levels.

Weed germination and dormancy are also influenced by fertilizer application. For example, germination of common lambsquarters seed from mother plants that received $280 \mathrm{~kg} \mathrm{ha}^{-1}$ of ammonium nitrate was greater than germination of seed from a mother plant where no $\mathrm{N}$ was applied, suggesting that $\mathrm{N}$ deficiency increased dormancy in seeds (Baskin and Baskin 1998; Fawcett and Slife 1978). According to Cairns and de Villiers (1986) the dormancy of several grass weed species was broken by ammonia, but the gas had no effect on the dormancy of dicotyledonous weed seed. Redroot pigweed (Amaranthus retroflexus L.) seed germination was also stimulated by 10 to 100 ppmv of ammonium nitrate or urea (Sardi and 
Beres 1996). Other researchers found that the chilling or light requirement for seed germination in some species can be replaced with N, particularly nitrate (Cohn et al. 1983; Egley and Duke 1985; Sexsmith and Pittman 1963; Steinbauer and Grigsby 1957).

Generally, fertilizer management strategies that favour crops over weeds deserve greater attention when weed infestations consist of species known to be highly responsive to higher soil nutrient (e.g. N) levels. In these situations farmers should consider the benefits of specific fertilizer timing and/or placement methods that would minimize weed interference (Blackshaw et al. 2004; Kirkland and Beckie 1998; Mesbah and Miller 1999).

\section{Biological control}

Biological control of weeds refers to the use of any kind of organism (micro or macro) to suppress weeds and reduce their harmful effects in agroecosystems. Plant pathogens are potentially valuable additions to the arsenal of weapons for use against weeds.

\subsection{Weed biological control approaches using pathogens}

Biological control of weeds using pathogens can be considered from two broad approaches including classical biological control (CBC) and inundative biological control (IBC) (Mohan babu et al. 2003).

\subsubsection{Classical biological control}

This approach is fairly simple in its concept: discover effective and highly host-specific agents from the weed's native geographic range, confirm their safety and effectiveness by rigorous experimental evaluation, and introduce them into regions where the weed has been newly introduced and requires control (Charudattan and Dinoor 2000). Host specificity tests provide the information on which to base the risk assessment and, thereby play the central role in any CBC project (Mohan babu et al. 2003).

Classical biological control by means of pathogens has been used in several parts of the world to control exotic weeds (Bruckart and Hasan 1991; Watson 1991). One of the most successful examples of classical biological control of weeds is the introduction of a rust fungus, Puccinia chondrillina, into Australia to control rush skeleton weed (Chondrilla juncea). A plant of Mediterranean origin, it became a serious weed in Australian cereal crops. The fungus, also from the Mediterranean was introduced along with three insects, as a classical biocontrol agent. Following the introduction and establishment, the fungus disseminated rapidly and widely and controlled the most common biotype of the weed (Cullen, 1985).

Other successful examples of classical biocontrol programs include the use of a smut fungus, Entyloma ageratinae, imported from Jamaica to control Hamakua pamakani (Ageratina riparia, Asteraceae) in Hawaiian forests and rangelands (Trujillo, 1985) and three other rust fungi, Puccinia carduorum, imported from Turkey and released into northeastern United States to control musk thistle (Carduus thoermeri) (Baudoin et al., 1993), Phragmidium violaceum to con- 
trol weedy species of Rubus in Chile (Oehrens, 1977) and Australia (Bruzzese, 1995) and Uromycladium tepperianum, to control an introduced invasive tree species, Acacia saligna in South Africa (Morris, 1997). The last fungus causes extensive gall formation on branches and twigs accompanied by a significant energy loss. Heavily infected trees are eventually killed (Charudattan and Dinoor 2000).

However, there is a potential problem in using biological control, namely, a shift in the weed population toward more resistant weed biotypes. Although, it also illustrates the possibility to counter the presence of natural resistance in weed populations by the introduction of new pathogen strains (Charudattan and Dinoor 2000).

\subsubsection{Inundative biological control}

The strategy of inundative biological control is to simulate natural epiphytotics of a selected pathogen within the population of the target weed species, early in the season and thus kill or at least significantly reduce the competitive ability of the weed and so prevent crop losses. This approach is typically used against endemic weeds, in which indigenous pathogens are mass-produced and applied as formulated products (bioherbicides) (Mohan babu et al. 2003). A bioherbicide is defined as a plant pathogen used as a weed-control agent through inundative and repeated applications of its inoculum (Charudattan and Dinoor 2000). The specificity of bioherbicides is considered as a positive attribute (Mohan babu et al. 2003).

Some examples of registered bioherbicides consisted of DeVine ${ }^{\circledR}$, composed of a Florida isolate of Phytophthora palmivora, is used for the control of Morrenia odorata (stranglervine or milkweed vine) in citrus in Florida. Collego®, based on Colletotrichum gloeosporioides f.sp. aeschynomene, is used to control Aeschynomene virginica (northern jointvetch), a leguminous weed in rice and soybean crops in Arkansas, Mississippi and Louisiana. BioMal ${ }^{\circledR}$, registered in Canada for the control of Malva pusilla (round-leaved mallow), containing Colletotrichum gloeosporioides f.sp. malvae, is presently unavailable for commercial use. The fourth bioherbicide, Dr. BioSedge ${ }^{\circledR}$, based on the rust fungus Puccinia canaliculata and registered for the control of Cyperus esculentus (yellow nutsedge) in the United States, is also unavailable for commercial use. An isolate of Xanthomonas campestris pv. poae, a wilt-inducing bacterium, isolated in Japan from Poa апnиa (annual bluegrass or wintergrass), is registered in Japan as the bioherbicide CAMPERICO ${ }^{\circledR}$ to control annual bluegrass in golf courses (Charudattan and Dinoor 2000).

Bioherbicides can make a significant contribution to weed control in the future, once the well-documented constraints have been overcome, particularly through improved target selection, formulation and marketing. The over-riding concern in using plant pathogens for weed control is their potential threat to non-targets (Mohan babu et al. 2003) which needs a serious attention.

\subsection{Microbial-derived herbicides}

Microbial-derived herbicides, especially microorganism secondary metabolites are a new kind of microbial herbicide to control weeds which are always phytotoxins. They are very 
different in chemical structure and size. These bioactive components invade into the host plant, cause pathogenicity, destroy their structure and lead them to produce necrotic lesions or chlorotic halo ( $\mathrm{Li}$ et al. 2003). They are less poisonous to most of mammalian systems, easily degraded and so far result in no biological disaster compared to chemical herbicides (Charudattan, 1991).

Phytotoxins used for microbial herbicides can be divided into three types: bacterial, fungal and actinomycete derived product. The pathogens which produce phytotoxins as a microbial herbicide must fit certain requirements: (1) be reproduced by biological technique, (2) grow fast after spraying or be capable of killing weeds within definite time, (3) suit industrial production and (4) be suitable for packaging, transport and use (Li et al. 2003).

In comparison with fungi, bacteria have some advantageous characteristics such as shortgrowth period, simple fermentation technique and easily controlled production process. In addition, bacteria can produce secondary metabolites unlike fungal spores, which need strict conditions for action as herbicides and their residues are easily degraded. Bacterial herbicides have a good prospect in application and exploitation (Li et al. 2003). Most of the bacteria with an ability to produce toxins are Gram-positive bacteria such as Pseudomonas, Erwinia, Xanthomonas but there are a few Gram-negative bacteria such as Streptomyces, Corynebacterium fasciomonads and some are non-fluorescent pseudomonads (Kremer et al., 1990).

Two phytotoxins from actinomycetes including herbicidines and herbimycins are higherplant toxins and produced by Streptomyces saganonensis. The former is used to control grassy weeds in paddy field as a selective herbicide, the latter controls monocotyledonous and dicotyledonous weeds (Stephen and Lydon, 1987).

However, the role of biomicrobial herbicides in agriculture is still problematic and insignificant (Mohan babu et al. 2003). Although, the current emphasis on lowering use of chemical herbicides may increase the production and use of biological-based herbicides in the future.

In general, the use of alternative weed control strategies can prevent or reduce the chemical herbicide application. This can lead to less reliance on fossil fuels (the non-renewable energy resources), lower environmental degradations and consequently a higher degree of sustainability for agroecosystems.

\section{Author details}

\section{G.R. Mohammadi}

Department of Crop Production and Breeding, Faculty of Agriculture and Natural Resources, Razi University, Kermanshah, Iran 


\section{References}

[1] Aarssen, L.W., 1992. Causes and consequences of variation in competitive ability in plant communities. J. Veg. Sci. 3, 165-174.

[2] Akanvou, R., L. Bastiaans, M. J. Kropff, J. Goudriaan and M. Becker. 2001. Characterization of Growth, Nitrogen Accumulation and Competitive Ability of Six Tropical Legumes for Potential Use in Intercropping Systems. Journal of Agronomy and Crop Science 187, 111-120.

[3] Akemo, M.C., Regnier, E.E. and Bennett, M.A. 2000. Weed suppression in springsown rye-pea cover crop mixes. Weed Technology 14, 545-549.

[4] Alcorta M., Fidelibus M. W., Steenwerth K. L. and Shrestha A. 2011. Effect of Vineyard Row Orientation on Growth and Phenology of Glyphosate-Resistant and Glyphosate-Susceptible Horseweed (Conyza canadensis). Weed Sc. 59(1):55-60.

[5] Alka“mper, J., E. Pessips, and D. V. Long. 1979. Einfluss der Dungung auf die Entwickelung und Nahrstoffnahme verschiedener Unkra ${ }^{\circ}$ uter in Mais. European Weed Research Society Symposium, Mainz, Germany. Paris: European Weed Research Society.

[6] Angiras, N. and V. Sharma. 1996. Influence of row orientation, row spacing and weed-control methods on physiological performance of irrigated wheat (Triticum aestivum). Indian J. Agron. 41:41-47.

[7] Angonin, C., J. P. Caussanel, and J. M. Meynard. 1996. Competition between winter wheat and Veronica hederifolia: influence of weed density and the amount and timing of nitrogen application. Weed Res. 36:175-187.

[8] Azanza, F., A. B. Zur, and J. Juvik. 1996. Variation in sweet corn characteristics associated with stand establishment and eating quality. Euphytica 87:7-18.

[9] Ball, D. A., Ogg, Jr., A. G. and Chevalier, P. M. 1997. The influence of seeding rate on weed control in small-red lentil (Lens culinaris). Weed Sci. 45: 296-300.

[10] Banks, P. A., P. W. Santelmann, and B. B. Tucker. 1976. Influence of long-term soil fertility treatments on weed species in winter wheat. Agron. J. 68:825-827.

[11] Barberi, P., 2002. Weed management in organic agriculture: are we addressing the right issues? Weed Res. 42, 177-193.

[12] Barnes, J. P., Putnam, A. R. and Burke, B. A. 1985. Allelopathic activity of rye (Secale cereale L.). In The Science of allelopathy (ed. A. R. Putnam and C. S. Tang), pp. 271-286. Wiley, New York.

[13] Barnes, J.P., Putnam, A.R., 1983. Rye residues contribute to weed suppression in notillage cropping systems. J. Chem. Ecol. 9, 1045-1057. 
[14] Barton, D. L., Thill, D. C. and Shafii, B. 1992. Integrated wild oat (Avena fatua) management affects spring barley (Hordeum vulgare) yield and economics. Weed Technol. 6: 129-135.

[15] Baskin, C. C. and J. M. Baskin. 1998. Seeds: Ecology, Biogeography, and Evolution of Dormancy and Germination. New York: Academic.

[16] Baudoin, A.B.A.M., Abad, R.G., Kok, L.T., Bruckart, W.L., 1993. Field evaluation of Puccinia carduorum for biological control of musk thistle. Biol. Control 3, 53-60.

[17] Begna, S. H., R. I. Hamilton, L. M. Dwyer, D. W. Stewart, D. Cloutier, L. Assemat, K. Foroutan-Pour, and D. L. Smith. 2001a. Weed biomass production response to plant spacing and corn (Zea mays) hybrids differing in canopy architecture. Weed Technol. 15:647-653.

[18] Begna, S. H., D. L. Smith, R. I. Hamilton, L. M. Dwyer, and D. W. Stewart. 2001b. Corn genotypic variation effects on seedling emergence and leaf appearance of shortseason areas. J. Agro. Crop Sci. 186:267-271.

[19] Belnap, J., S. K. Sherrod, and M. E. Miller. 2003. Effects of soil amendments on germination and emergence of downy brome (Bromus tectorum) and Hilaria jamesii. Weed Sci. 51:371-378.

[20] Bennett, A. C. and D. R. Shaw. 2000. Effect of Glycine max cultivar and weed control on weed seed characteristics. Weed Sci. 48:431-435.

[21] Berkowitz, A. R. 1988. Competition for resources in weed-crop mixtures. Pages 89119 in M. A. Altieri and M. Liebman, eds. Weed management in agroecosystems: Ecological approaches. CRC Press, Inc., Boca Raton, FL.

[22] Bhowmik P. C. and Inderjit. 2003. Challenges and opportunities in implementing allelopathy for natural weed management. Crop Prot 22: 661-671.

[23] Bhowmik, P.C., 1988. Cinmethylin for weed control in soybeans, Glycine max. Weed Sci. 36, 678-682.

[24] Black, J.N., 1958. Competition between plants of different initial seed sizes in swards of subterranean clover (Trifolium subterraneum L.) with particular reference to leaf area and light microclimate. Aust J Agric Res 9: 299-318.

[25] Blackshaw R. E. 2005. Nitrogen fertilizer, manure, and compost effects on weed growth and competition with spring wheat. Agron. J. 97:1612-1621.

[26] Blackshaw R. E. and Molnar L. J. 2009. Phosphorus fertilizer application method affects weed growth and competition with wheat. Weed Sci. 57:311-318.

[27] Blackshaw R. E., Molnar L. J. and Larney F. J. 2005. Fertilizer, manure and compost effects on weed growth and competition with winter wheat in western Canada. Crop Protection 24: 971-980. 
[28] Blackshaw, R. E., L. J. Molnar, and H. H. Janzen. 2004. Nitrogen fertilizer timing and application method affect weed growth and competition with spring wheat. Weed Sci. 52: 614-622.

[29] Blackshaw, R. E., R. L. Anderson, and D. Lemerle. 2007. Cultural weed management. Pages 35-47 in M. K. Upadhyaya and R. E. Blackshaw, eds. Non-Chemical Weed Management: Principles, Concepts and Technology. Oxfordfordshire, UK: CABI.

[30] Blackshaw, R.E., 1994. Differential competitive ability of winter wheat cultivars against Downy brome. Agron. J. 86, 649-654.

[31] Blackshaw, R.E., Brandt, R.N., Janzen, H.H., Entz, T., Grant, C.A., Derksen, D.A., 2003. Differential response of weed species to added nitrogen. Weed Sci. 51: 532-539.

[32] Bond W. and Grundy A. C. 2001. Non-chemical weed management in organic farming systems. Weed Res., 41, 383-405.

[33] Borger C. P. D., Hashem A. and Pathan S. 2010. Manipulating crop row orientation to suppress weeds and increase crop yield. Weed Sci. 58:174-178.

[34] Börner. 1960. Liberation of organic substances from higher plants and their role in the soil sickness problem. The Botanical Review 26, 396-424.

[35] Boydston, R.A., Hang, A., 1995. Rapeseed (Brassica napus) green manure crop suppresses weeds in potato (Solanum tuberosum). Weed Technol. 9, 669-675.

[36] Brainard, D.C. and Bellinder, R.R. 2004. Weed suppression in a broccoli-winter rye intercropping system. Weed Science 52, 281-290.

[37] Brainard, D.C., Bellinder, R.R., Miller, A.J., 2004. Cultivation and interseeding for weed control in transplanted cabbage. Weed Technol. 18, 704-710.

[38] Brandsaeter, L.O., Netland, J., 1999. Winter annual legumes for use as cover crops in row crops in northern regions: I. Field experiments. Crop Sci. 39, 1369-1379.

[39] Bruckart, W.L., Hasan, S., 1991. Options with plant pathogens intended for classical control of range and pasture weeds. In: TeBeest, D.O. (Ed.), Microbial Control of Weeds. Chapman and Hall, New York, pp. 69-79.

[40] Bruzzese, E., 1995. Present status of biological control of European blackberry (Rubus fruticosus aggregate in Australia. In: Delfosse, E.S., Scott, R.R. (Eds.), Proceedings of the Eighth International Symposium on Biological Control of Weeds. DSIR/CSIRO. Melbourne, Australia, pp. 297-299.

[41] Bussan, A.J., O.C. Burnside, J.H. Orf, E.A. Ristau, and K.J. Puettmann. 1997. Field evaluation of soybean (Glycine max) genotypes for weed competitiveness. Weed Sci. 45:31-37.

[42] Cairns, A.L.P. and O. T. de Villiers. 1986. Breaking dormancy of Avena fatua L. seed by treatment with ammonia. Weed Res. 26:191-198. 
[43] Callaway, M.B. 1992. A compendium of crop varietal tolerance to weeds. Am. J. Alternative Agric. 7:169-180.

[44] Callaway, M.B., and F. Forcella. 1993. Crop tolerance to weeds. p. 100-131. In C.A. Francis and M.B. Callaway (ed.) Crop improvement for sustainable agriculture. Univ. Nebraska Press, Lincoln.

[45] Campiglia E., Paolini R., Colla G. and Mancinelli R. 2009. The effects of cover cropping on yield and weed control of potato in a transitional system. Field Crops Research 112, 16-23.

[46] Carmona, D. M. and D. A. Landis. 1999. Influence of refuge habitats and cover crops on seasonal-density of ground beetles (Coleoptera: Carabidae) in field crops. Environ. Entomol. 28:1145-1153.

[47] Cathcart, R. J. and C. J. Swanton. 2003. Nitrogen management will influence threshold values of green foxtail (Setaria viridis) in corn. Weed Sci. 51:975-986.

[48] Charudattan, 1991. The mycoherbicide approach with plant pathogens. In: TeBeest, D.O. (Ed.), Microbial Control of Weeds. Chapman and Hall, New York, pp. 24-57.

[49] Charudattan, R., Dinoor, A., 2000. Biological control of weeds using plant pathogens: accomplishments and limitations. Crop Prot. 19, 691-695.

[50] Chauhan B. S. and Johnson D. E. 2011. Row spacing and weed control timing affect yield of aerobic rice. Field Crops Res. 121:226-231.

[51] Chou, C. H. 1999. Roles of allelopathy in plant biodiversity and sustainable agriculture. Critical Rev. Plant Sci. 18:609-636.

[52] Cohn, M. A., D. L. Butera, and J. A. Hughs. 1983. Seed dormancy in red rice, III: response to nitrite, nitrate, and ammonium ions. Plant Physiol 73:381-384.

[53] Collins A. S., Chase C. A., Stall W. M. and Hutchinson C. M. 2008. Optimum Densities of Three Leguminous Cover Crops for Suppression of Smooth Pigweed (Amaranthus hybridus). Weed Science 56, 753-761.

[54] Conklin, A. E., M. S. Erich, M. Liebman, D. Lambert, E. R. Gallandt, and W. A. Halteman. 2002. Effects of red clover (Trifolium pratense) green manure and compost soil amendments on wild mustard (Brassica kaber) growth and incidence of disease. Plant Soil 238:245-256.

[55] Copaja, S. V., Nicol, D. and Wratten, S. D. 1999. Accumulation of hydroxamic acids during wheat germination. Phytochemistry 50, 17-24.

[56] Cousens, R., and Mortimer, M. 1995. Dynamics of Weed Populations. Cambridge University Press, Cambridge.

[57] Creamer, N. G., Bennett, M. A., Stinner, B. R., Cardina, J. and Regnier, E. E. 1996. Mechanisms of weed suppression in cover crop-based production systems. Hort science $31,410-413$. 
[58] Cromar, H. E., Murphy, S. D., and Swanton, C. J. 1999. Influence of tillage and crop residue on post dispersal predation of weed seeds. Weed Science, 47, 184-194.

[59] Crotser, M. P. and W. W. Witt. 2000. Effect of Glycine max canopy characteristics, G. max interference, and weed free period on Solanum ptycanthum growth. Weed Sci. 48:20-26.

[60] Cullen, J.M., 1985. Bringing the cost benefit analysis of biological control of Chondrilla juncea up to date. In: Delfosse, E.S. (Ed.), Proceedings of the VI International Symposium on Biological Control of Weeds. Agriculture Canada, Ottawa, pp. 145-152.

[61] Czarnota, M.A., A.M. Rimando, and L.A. Weston. 2003. Evaluation of root exudates of seven sorghum accessions. J. Chem. Ecol. 29: 2073-2083.

[62] Daferera, D. J., B. N. Ziogas, and M. G. Polissiou. 2003. The effectiveness of plant essential oils on the growth of Botrytis cinerea, Fusarium sp. and Clevibacter michiganensis subsp. michiganensis. Crop Prot. 22:39-44.

[63] Daughtry, C.S.T., Gallo, K.P., Bauer, M.E., 1983. Spectral estimates of solar radiation intercepted by corn canopies. Agron. J. 72, 527-531.

[64] Davis, A. S. and M. Liebman. 2001. Nitrogen source influences wild mustard growth and competitive effect on sweet corn. Weed Sci. 49:558-566.

[65] Davis, A. S. and M. Liebman. 2003. Cropping system effects on Setaria faberi seed bank dynamics. Aspects Appl. Biol. 69:83-91.

[66] Dayan, F.E. 2002. Natural pesticides. p. 521-525. In D. Pimentel (ed.) Encyclopedia of pest management. Marcel Dekker, Inc., New York.

[67] Dayan, F.E., J.G. Romagni, M. Tellez, A. Rimando, and S. Duke. 1999. Managing weeds with bio-synthesized products. Pestic. Outl. 10: 185-188.

[68] De Haan R. L., D. L. Wyse, N. J. Ehlke, B. D. Maxwell, and D. H. Putnam. 1994. Simulation of spring-seeded smoother plants for weed control in corn (Zea mays). Weed Sci. $42,35-43$.

[69] den Hollander N. G., Bastiaans L. and Kropff M. J. 2007. Clover as a cover crop for weed suppression in an intercropping design I. Characteristics of several clover species. Europ. J. Agronomy 26: 92-103.

[70] Dhima, K. V., I. B. Vasilakoglou, Th. D. Gatsis, E. Panou-Philotheou, and I. G. Eleftherohorinos. 2009. Effects of aromatic plants incorporated as green manure on weed and maize development. Field Crops Res. 110:235-241.

[71] Di Tomaso JM 1995 Approaches for improving crop competitiveness through the manipulation of fertilization strategies. Weed Sci 43: 491-497.

[72] Dilday, R. H., Lin, J. and Yan, W. 1994. Identification of allelopathy in the Usda-Ars rice germplasm collection. Australian Journal of Experimental Agriculture 34, 907-910. 
[73] Dilday, R.H., Mattice, J.D., Moldenhauer, K., Yan, AW., 2001. Allelopathic potential in rice germplasm against ducksalad, redstem and barnyard grass. J. Crop Prod. 4, 287-301.

[74] Dingkuhn M., Johnson D.E., Sow A. and Audebert A.Y. 1999. Relationships between upland rice canopy characteristics and weed competitiveness. Field Crops Res. 61, 79-95.

[75] Dotzenko, A. D., M. Ozkan, and K. R. Storer. 1969. Influence of crop sequence, nitrogen fertilizer and herbicides on weed seed populations in sugar beet fields. Agron. J. 61:34-37.

[76] Drews S., Juroszek P., Neuhoff D., Kopke U. 2004. Optimizing shading ability of winter wheat stands as a method of weed control. J. Plant Dis. Prot.:545-552.

[77] Dudai, N., A. Poljakoff-Mayber, A. M. Mayer, E. Putievsky, and H. R. Lerner. 1999. Essential oils as allelochemicals and their potential use as bioherbicides. J. Chem. Ecol. 25:1079-1089.

[78] Duke, S.O., Dayan, F.E., Ramagni, J.G., Rimando, A.M., 2000. Natural products as sources of herbicides: current status and future trends. Weed Res. 40: 99-111.

[79] Duke, S.O., Dayan, F.E., Rimando, R.M., Schrader, K.K., Aliotta, G., Oliva, A., Romagni, J.G., 2002. Chemicals from nature for weed management. Weed Sci. 50, 138151.

[80] Duke, S.O., Vaughn, K.C., Croom, E.M., Elsohly, H.N., 1987. Artemisinin, a constituent of annual wormwood (Artemisia annua) is a selective phytotoxin. Weed Sci. 35, 499-505.

[81] Dyck, E. and M. Liebman. 1994. Soil fertility management as a factor in weed control: the effect of crimson clover residue, synthetic nitrogen fertilizer, and their interaction on emergence and early growth of lambsquarters and sweet corn. Plant Soil 167:227237.

[82] Dyck, E., M. Liebman, and M. S. Erich. 1995. Crop-weed interference as influenced by a leguminous or synthetic fertilizer nitrogen source: I. Double cropping experiments with crimson clover, sweet corn, and lambsquarters. Agric. Ecosyst. Environ. 56:93-108.

[83] Egley, G. H. and S. O. Duke. 1985. Physiology of weed seed dormancy and germination. Pages 27-64 in Weed Physiology: Reproduction and Ecophysiology, Volume 1. Boca Raton, FL: CRC.

[84] Einhellig, F.A., and J.A. Rasmussen. 1989. Prior cropping with grain sorghum inhibits weeds. J. Chem. Ecol. 15:951-960.

[85] Entz, M.H., W.J. Bullied, and F. Katepa-Mupondwa. 1995. Rotational benefits of forage crops in Canadian prairie cropping systems. J. Prod. Agric. 8:521-529. 
[86] Evans S.P., Knezevic S.Z., Shapiro C., Lindquist J.L. 2003. Nitrogen level affects critical period for weed control in corn. Weed Sci 51: 408-417.

[87] Facelli, J. M., and S. T. A. Pickett. 1991. Plant litter, It's dynamics and effects on plant community structure. Bot. Rev. 57,1-32.

[88] Fawcett, R. S. and F. W. Slife. 1978. Effects of field applications of nitrate on weed seed germination and dormancy. Weed Sci. 26:594-596.

[89] Fay, P. K. and Duke, W. B. 1977. An assessment of allelopathic potential in Avena germplasm. Weed Science 25, 224-228.

[90] Fujii, Y. 1999. Allelopathy of hairy vetch and Macuna; their application for sustainable agriculture. pp.289-300. In C.H. Chou et al. Biodiversity and Allelopathy from Organisms to Ecosystems in the Pacific. Academia Sinica, Taipei.

[91] Gallandt, E. R., T. Molloy, R. P. Lynch, and F. A. Drummond. 2005. Effect of covercropping systems on invertebrate seed predation. Weed Sci. 53:69-76.

[92] Garrity, D.P., M. Movillon, and K. Moody. 1992. Differential weed suppression ability in upland rice cultivars. Agron. J. 84:586-591.

[93] Gaudet, C.L., Keddy, P.A., 1988. A comparative approach to predicting competitive ability from plant traits. Nature 334, 242-243.

[94] Gianoli, E. and Niemayer, H. M. 1998. DIBOA in wild Poaceae: Source of resistance to the Russian wheat aphid (Diuraphis noxia) and the greenbug (Schizaphis graminum). Euphytica 102, 317-321.

[95] Girardin, Ph. and Tollenaar, M. 1994. Effects of intraspecific interference on maize leaf azimuth. Crop Sci. 34: 151-155.

[96] Goldberg, D.E., 1990. Components of resource competition in plant communities. In: Grace, J.B., Tilman, D. (Eds.), Perspectives on Plant Competition. Academic Press, San Diego, pp. 27-49.

[97] Gonzalez, V.M., Kazimir, J., Nimbal, C., Weston, L.A., Cheniae, G.M., 1997. Inhibition of a photosystem II electron transfer reaction by the natural product sorgoleone. J. Agric. Food Chem. 45, 1415-1421.

[98] Gooding, M.J., A.J. Thompson, and W.P. Davies. 1993. Interception of photosynthetically active radiation, competitive ability, and yield of organically grown wheat varieties. Aspects Appl. Biol. 34:355-362.

[99] Grace J.B. 1990. On the relationship between plant traits and competitive ability. In: Perspective on Plant Competition (ed. by Grace J.B. and Tilman D.). Academic Press, San Diego, CA, 51-65.

[100] Grant, C. A., D. N. Flaten, D. J. Tomasiewicz, and S. C. Sheppard. 2001. The importance of early season phosphorus nutrition. Can. J. Plant Sci. 81:211-224. 
[101] Grime J.P. 1977. Evidence for the existence of three primary strategies in plants and its relevance to ecological and evolutionary theory. Am. Nat. 111, 1169-1194.

[102] Hall M. R., Swanton C. J. and Anderson G. W. 1992. The critical period of weed control in grain corn (Zea mays). Weed Sci 40: 441-447.

[103] Hallberg G. R. 1989. Pesticide pollution of ground water in the humid United States. Agric. Ecosyst. Environ. 26, 299-367.

[104] Harker, K.N., J.T. O’Donovan, R.B. Irvine, T.K. Turkington, and G.W. Clayton. 2009. Integrating cropping systems with cultural techniques augments wild oat (Avena fatua) management in barley. Weed Sci. 57:326-337.

[105] He, H.Q., L.H. Shen, J. Xiong, X.L. Jia, W.X. Lin, and H. Wu. 2004. Conditional genetic effect of allelopathy in rice (Oryza sativa L.) under different environmental conditions. Plant Grow. Reg. 44: 211-218.

[106] Henson, J. F. and Jordan, L. S. 1982. Wild oat (Avena fatua) competition with wheat (Triticum aestivum and T. turgidum Durum) for nitrate. Weed Sci., 30: 297-300.

[107] Hinson,K., andW.D.Hanson. 1962. Competition studies on soybeans. Crop Sci. 2:117123.

[108] Hoffman, M.L., M.D.K. Owen, and D.D. Buhler. 1998. Effects of crop and weed management on density and vertical distribution of weed seeds in soil. Agron. J. 90:793799.

[109] Holt J. S. and LeBaron H. N. 1990. Significance and distribution of herbicide resistance. Weed Technol. 4, 141-149.

[110] Holt J.S. and Ocrutt D.R. 1991. Functional relationships of growth and competitiveness in perennial weeds and cotton (Gossypium hirsutum). Weed Sci. 39, 575-584.

[111] Holt, J. S. 1995. Plant responses to light: a potential tool for weed management. Weed Sci. 43:474-482.

[112] Hucl, P. 1998. Response to weed control by four spring wheat genotypes differing in competitive ability. Can. J. Plant Sci. 78:171-173.

[113] Huel, D.G. and P. Hucl, 1996. Genotypic variation for competitive ability in spring wheat. Plant Breed 115: 325-329.

[114] Hunt, R., and J.H.C. Cornelissen. 1997. Components of relative growth rate and their interrelations in 59 plant species. New Phytol. 135:395-417.

[115] Inderjit and Olofsdotter M. 1998. Using and improving laboratory bioassays in rice allelopathy research. In Allelopathy in Rice. Proceedings of the workshop on Allelopathy in Rice, 25-27 Nov. 1996 (ed. M. Olofsdotter), pp. 45-55. IRRI, Manilla.

[116] Isman, B. M. 2000. Plant essential oils for pest and disease management. Crop Prot. 19:603-608. 
[117] Jannink, J. L., N. R. Jordan, and J. H. Orf. 2001. Feasibility of section for high weed suppressive ability in soybean: absence of tradeoffs between rapid initial growth and sustained later growth. Euphytica 120:291-300.

[118] Jannink, J.L., Orf, J.H., Jordan, N.R., Shaw, R.G., 2000. Index selection for weed suppressive ability in soybean. Crop Sci. 40, 1087-1094.

[119] Jensen, L.B., Courtois, B., Shen, L., Li, Z., Olofsdotter, M., Mouleon, R.D. 2001. Locating genes controlling allelopathic effect against barnyardgrass in upland rice. Agron. J. 93: $21-26$.

[120] Johnson D.E., Ding Kuhn M., Jones M.P. and Mahamane M.C. 1998. The influence of rice plant type on the effect of weed competition on Oryza sativa and Oryza glaberrima.Weed Res. 38: 207-216.

[121] Jordan N. 1993. Prospects for weed control through interference. Ecol. Appl. 3, 84-91.

[122] Keddy, P.A., Shipley, B., 1989. Competitive hierarchies in herbaceous plant communities. Oikos 54: 234-241.

[123] Khan, M., Donald, W. W. and Prato, T. 1996. Spring wheat (Triticum aestivum) management can substitute for diclofop for foxtail (Setaria spp.) control. Weed Sci. 44: 362-372.

[124] Kirkland, K. J. 1993. Weed management in spring barley (Hordeum vulgare) in the absence of herbicides. J. Sustain. Agric. 3: 95-104.

[125] Kirkland, K. J. and H. J. Beckie. 1998. Contribution of nitrogen fertilizer placement to weed management in spring wheat (Triticum aestivum). Weed Technol. 12:507-514.

[126] Knezevic S. Z., Evans S. P., Blankenship E. E., Van Acker R. C. and Lindquist J. L. 2002. Critical period for weed control: the concept and data analysis. Weed Sci 50: 773-786.

[127] Kohli, R.K., Batish, D., Singh, H.P., 1998. Allelopathy and its implications in agroecosystems. J. Crop Prod. 1, 169-202.

[128] Kollman, G.E., J.G. Streeter, D.L. Jeffers and R.B. Curry, 1979. Accumulation and distribution of mineral nutrients, carbohydrate, and dry matter in soybean plants as influenced by reproductive sink size. Crop Sci 19: 729-734.

[129] Kremer, R. J. 1993. Management of weed seed banks with microorganisms. Ecol. Appl. 3:42-52.

[130] Kremer, R.J., Begonia, M.F.T., Stanley, L., Lanham, E.T., 1990. Characterization of rhizobacteria associated with weed seedlings. Appl. Environ. Microbiol. 56, 1649-1655.

[131] Kristensen L., Olsen J. and Weiner J. 2008. Crop density, sowing pattern, and nitrogen fertilization effects on weed suppression and yield in spring wheat. Weed Sci. 56:97-102 
[132] Kropff, M.J., and H.H. van Laar. 1993. Modeling crop-weed interactions. CAB International, Wallingford, UK.

[133] Kruidhof, H. M., Bastiaans L. and Kropff M. J. 2008. Ecological weed management by cover cropping, effects on weed growth in autumn and weed establishment in spring. Weed Res., 48, 492-502.

[134] Kruse, M., Strandberg, M. and Strandberg, B. 2000. Ecological effects of allelopathic plants - A Review. National Environmental Research Institute, Silkeborg, Denmark. 66 pp. - NERI Technical Report No. 315.

[135] Kumar, V., D. C. Brainard, and R. R. Bellinder. 2008. Suppression of Powell amaranth (Amaranthus powellii), shepherd's-purse (Capsella bursa-pastoris), and corn chamomile (Anthemis arvensis) by buckwheat residues: role of nitrogen and fungal pathogens. Weed Sci. 56:271-280.

[136] Leather, G.R., 1983a. Sunflowers (Helianthus annuus) are allelopathic to weeds. Weed Sci. 31, 37-42.

[137] Leather, G.R., 1983b. Weed control using allelopathic crop plants. J. Chem. Ecol. 9, 983-990.

[138] Leather, G.R., 1987. Weed control using allelopathic sunflowers and herbicide. Plant Soil 98, 17-23.

[139] Lemerle, D., Verbeek, B., Cousens, R.D., Coombes, N.E., 1996. The potential for selecting wheat varieties strongly competitive against weeds. Weed Res. 36, 505-513.

[140] Li, Y., Sun, Z., Zhuang, X., Xu, L., Chen, S., Li, M., 2003. Research progress on microbial herbicides. Crop Prot. 22, 247-252.

[141] Liebman, M., and E. Gallandt. 1997. Many little hammers: ecological approaches for management of crop-weed interactions. p. 291-343. In L.E. Jackson (ed.) Ecology in Agriculture. Academic Press, San Diego.

[142] Lindquist, J. L. and D. A. Mortensen. 1998. Tolerance and velvetleaf (Abutilon theophrasti) suppressive ability of two old and two modern corn (Zea mays) hybrids. Weed Sci. 46:569-574.

[143] Lindquist, J. L. and M. J. Kropff. 1996. Applications of an ecophysiological model for irrigated rice (Oryza sativa) - Echinochloa competition. Weed Sci 44:52-56.

[144] Lindquist, J. L., D. A. Mortensen, and B. E. Johnson. 1998. Mechanisms of corn tolerance and velvetleaf suppressive ability. Agron. J. 90:787-792.

[145] Lovett, J. V. and Hoult, A. H. C. 1995. Allelopathy and self-defence in barley. In Allelopathy. Organisms, Processes, and Applications. (ed. Inderjit, K. M. M. Dakshini and F. A. E. (eds.).), pp. 170-183. American Chemical Society, Washington, DC.

[146] Lybecker D. W., Schweizer E. E. and King R. P. 1988. Economic analysis of four weed management systems. Weed Sci. 36, 846-849. 
[147] Macias, F. A. 1995. Allelopathy in the search for natural herbicides models. In Allelopathy. Organisms, Processes and Applications (ed. K. M. M. Inderjit and E. F.A.), pp. 310-329. American Chemical Society.

[148] Macias, F. A., Simonet, A. M., Galindo, J. C. G., Pacheco, P. C. and Sanchez, J. A. 1998. Bioactive polar triterpenoids from Melilotus messanensis. Phytochemistry 49, 709-717.

[149] Macias, F.A., Varela, R.M., Torres, A., Molinillo, J.M.G., 1999. Potential of cultivar sunflowers (Helianthus annuus L.) as a source of natural herbicide template. In: Inderjit, Dakshini, K.M.M., Foy, C.L. (Eds.), Principles and Practices in Plant Ecology: Allelochemical Interactions. CRC Press, Boca Raton, FL, pp. 531-550.

[150] McDonald, G. K. 2003. Competitiveness against grass weeds in field pea genotypes. Weed Res. 43: 48-58.

[151] McWhorter, C.G., and E.E. Hartwig. 1972. Competition of johnsongrass and cocklebur with six soybean varieties. Weed Sci. 20: 56-59.

[152] Mesbah, A. O. and S. D. Miller. 1999. Fertilizer placement affects jointed goatgrass (Aegilops cylindrica) competition in winter wheat (Triticum aestivum). Weed Technol. 13: 374-377.

[153] Meschede, D. K., Ferreira, A. B. and Ribeiro Junior, C. C. 2007. Evaluation of weed suppression using different crop covers under Brazilian cerrado soil conditions. Planta Daninha, 25, 465-471.

[154] Miller, D. A. 1996. Allelopathy in forage crop systems. Agronomy Journal 88: 854-859.

[155] Mohammadi G. R. 2007. Growth parameters enhancing the competitive ability of corn (Zea mays L.) against weeds. Weed Biology and Management. 7: 232-236.

[156] Mohammadi G. R. and F. Amiri. 2011. Critical period of weed control in soybean (Glycine max) as influenced by starter fertilizer. Australian Journal of Crop Science. 5: 1350-1355.

[157] Mohammadi G. R. 2012. Living mulch as a tool to control weeds in agroecosystems: A Review. In: Price, A. J. (Ed.), Weed Control. InTech Press, Croatia. pp. 75-100.

[158] Mohammadi G. R., Kahrizi, D. and Rashidi, N. 2009. Evaluation of sorghum (Sorghum bicolor (L.) Moench) ability to control weeds in corn (Zea mays L.). Korean Journal of Weed Science. 29: 104-111.

[159] Mohammadi, G. R. 2009. The effects of legumes as living mulches on weed control and plant traits of corn (Zea mays L.). Korean Journal of Weed Science 29: 222-228.

[160] Mohammadi, G. R. 2010. Weed control in corn (Zea mays L.) by hairy vetch (Vicia villosa L.) interseeded at different rates and times. Weed Biology and Management 10: 25-32. 
[161] Mohammadi, G. R., M. E. Ghobadi and S. Sheikheh Poor. 2012. Phosphate biofertilizer, row spacing and plant density effects on corn (Zea mays L.) yield and weed growth. American Journal of Plant Sciences. 3: 425-429.

[162] Mohammadi G. R., Mozafari S., Ghobadi M. E. and Najaphy A. 2012. Weed suppressive ability and productivity of berseem clover interseeded at different rates and times in corn field. The Philippine Agricultural Scientist 95:146-152.

[163] Mohan Babu R., Sajeena A., Seetharaman K., Vidhyasekaran P., Rangasamy P., Som Prakash M, Senthil Raja A. and Biji K. R. 2003. Advances in ioherbicides development-an overview. Crop Protection 22: 253-260.

[164] Moharramipour, S., Takeda, K., Sato, K., Yoshida, H. and Tsumuki, H. 1999. Inheritance of gramine in barley. Euphytica 106, 181-185.

[165] Mohler, C. L. 1996. Ecological bases for the cultural control of annual weeds. J. Prod. Agric. 9: 468-474.

[166] Mohler, C. L. 2001. Enhancing the competitive ability of crops. Pages 269-321 in M. Liebman, C. L. Mohler, and C. P. Staver, eds. Ecological Management of Agricultural Weeds. Cambridge, UK: Cambridge University Press.

[167] Mohler, C. L. and J. R. Teasdale. 1993. Response of weed emergence to rate of Vicia villosa Roth and Secale cereale L. residue. Weed Res. 33:487-499.

[168] Mohler, C. L. and M. B. Callaway. 1991. Effects of tillage and mulch on emergence and survival of weeds in sweet corn. J. Appl. Ecol. 29:21-34.

[169] Monks, D.W., and L.R. Oliver. 1988. Interactions between soybean (Glycine max) cultivars and selected weeds. Weed Sci. 36:770-774.

[170] Morris, M.J., 1997. Impact of the gall-forming rust fungus Uromycladium tepperianum on the invasive tree Acacia saligna in South Africa. Biol. Control 10, 75-82.

[171] Mutsaers, H.J.W. 1980. The effect of row orientation, date and latitude on light absorption by row crops. J. Agric. Sci. 95:381-386.

[172] Narwal, S. S. 1996. Potentials and prospects of allelopathy mediated weed control for sustainable agriculture. In Allelopathy in Pest Management for Sustainable Agriculture. Procceding of the International Conference on Allelopathy, vol. 11 (ed. S. S. Narwal and P. Tauro), pp. 23-65. Scientific Publishers, Jodhpur.

[173] Navas Marie-Laure and Moreau-Richard J. 2005. Can traits predict the competitive response of herbaceous Mediterranean species? Acta Oecologica. 27: 107-114.

[174] Niemeyer, H. M. and Jerez, J. M. 1997. Chromosomal location of genes for hydroxamic acids accumulation in Triticum aestivum $\mathrm{L}$ (wheat) using wheat aneuploids and wheat substitution lines. Heredity 79, 10-14. 
[175] Nimbal, C.I., J.F. Pedersen, C.N. Yerkes, L.A.Weston, and S.C.Weller. 1996a. Phytotoxicity and distribution of sorgoleone in grain sorghum germplasm. J. Agric. Food Chem. 44:1343-1347.

[176] Nimbal, C.I., Yerkes, C.N., Weston, L.A., Weller, S.C., 1996b. Herbicidal activity and site of action of the natural product sorgoleone. Pest Chem. Physiol. 54, 73-83.

[177] O'Donovan, J. T. and Newman, J. C. 1996. Manipulation of canola (Brassica rapa) plant density and herbicide rate for economical and sustainable weed management. Proc. of the $2^{\text {nd }}$ International Weed Control Congress, 25-28 June 1996, Copenhagen, Denmark. Department of Weed Control and Pesticide Ecology, Flakkebjerg, DK-4200 Slagelse, Denmark. pp. 969-974.

[178] O’Donovan, J. T., Harker, K. N., Clayton, G. W. and Hall, L. M. 2000. Wild oat (Avena fatua) interference in barley (Hordeum vulgare) is influenced by barley variety and seeding rate. Weed Technol. 14: 624-629.

[179] Oehrens, E., 1977. Biological control of the blackberry through the introduction of rust, Phragmidium violaceum, in Chile. FAO Plant Protect. Bull. 25, 26-28.

[180] Olofsdotter, M., L.B. Jensen, and B. Courtois. 2002. Improving crop competitive ability using allelopathy - an example from rice. Plant Breed. 121:1-9.

[181] Olofsdotter, M., Navarez, D. and Rebulanan, M. 1997. Rice allelopathy - Where are we and how far can we get? In The 1997 Brighton Crop protection Conference, vol. l, pp. 99-104, Brighton.

[182] Olsen, J. and J. Weiner. 2007. The influence of Triticum aestivum density, sowing pattern and nitrogen fertilization on leaf area index and its spatial variation. Basic Appl. Ecol. 8:252-257.

[183] Ominski, P.D., M.H. Entz, and N. Kenkel. 1999. Weed suppression by Medicago sativa in subsequent cereal crops: A comparative survey. Weed Sci. 47:282-290.

[184] Openshaw, S.J., H.H. Hadley and C.E. Brokoski, 1979. Effects of pod removal upon seeds of nodulations and non-nodulating soybean lines. Crop Sci 19: 289-290.

[185] Overland, L. 1966. The role of allelopathic substances in the "smother crop" barley. Amer. J. Bot. 53, 423-432.

[186] Paolini, R., M. Principi, R. J. Froud-Williams, S. Del Puglia, and E. Binacardi. 1999. Competition between sugarbeet and Sinapis arvensis and Chenopodium album, as affected by timing of nitrogen fertilization. Weed Res. 39:425-440.

[187] Petersen, J. 2003. Weed-spring barley competition for applied nitrogen in pig slurry. Weed Res. 43:33-39.

[188] Petho, M. 1992. Occurrence and physiological role of benzoxazinones and their derivates. IV. isolation of hydroxamic acids from wheat and rye root secretions. Acta Agronomica Hungarica 41, 167-175. 
[189] Phatak, S. C. 1992. An integrated sustainable vegetable production system. Hort. Sci. $27,738-741$.

[190] Qasem, J. R. 1992. Root growth, development and nutrient uptake of tomato (Lycopersicon esculentum) and Chenopodium album. Weed Res. 33:35-42.

[191] Rajalahti, R. M., Bellinder, R. R. and Hoffman, M. P. 1999. Time of hilling and interseeding affects weed control and potato yield. Weed Science 47, 215-225.

[192] Rajcan, I., M. AghaAlikhani, C. J. Swanton, and M. Tollenaar. 2002. Development of redroot pigweed is influenced by light spectral quality and quantity. Crop Sci. 42:1930-1936.

[193] Randall, H.W.,Worsham, D., Blum,W., 1989. Allelopathic potential of legume debris and aqueous extracts. Weed Sci. 37, 674-679.

[194] Rasmussen, K. 2002. Influence of liquid manure application method on weed control in spring cereals. Weed Res. 42:287-298.

[195] Reich, P.B., M.B. Walters and D.S. Ellsworth, 1997. From tropics to tundra: Global convergence in plant functioning. Proc Natl Acad Sci (USA) 94: 13730-13734.

[196] Rice, E.L. 1984. Allelopathy. 2nd ed. Academic Press, New York.

[197] Rice, E.L. 1995. Biological control of weeds and plant diseases. Univ. Oklahoma Press, Norman.

[198] Rimando, A.M., Olofsdotter, M., Dayan, F.E., Duke, S.O., 2001. Searching for rice allelochemicals: an example of bioassay-guided isolation. Agron. J. 93, 16-20.

[199] Rizvi, S. H. and V. Rizvi. 1992. Allelopathy-Basic and Applied Aspects. 1st ed. London: Chapman and Hall. 480 p.

[200] Rodenburg, J., Saito, K., Kakai, R.G., Toure, A., Mariko, M., Kiepe, P., 2009. Weed competitiveness of the lowland rice varieties of NERICA in the southern Guinea Savanna. Field Crops Res. 114, 411-418.

[201] Ross, M.A. and J.L. Harper, 1972. Occupation of biological space during seedling establishment. J Ecol 60: 77-88.

[202] Ross, S. M., King, J. R., lzaurralde, R. C. and O’Donovan, J. T. 2001. Weed suppression by seven clover species. Agronomy Journal 93, 820-827.

[203] Ross, M.A. and Lembi, C.A., 1985. Applied Weed Science. Burgees Pub. Co.

[204] Saito K., Azoma K. and Rodenburg J. 2010. Plant characteristics associated with weed competitiveness of rice under upland and lowland conditions in West Africa. Field Crops Res., 116: 308-317.

[205] Samson, R. A. 1991. The weed suppressing effects of cover crops. Pages 11-22 in Fifth Annual REAP Conference, Macdonald College, Ste.-Anne-de-Bellevue, Quebec. 
[206] Sankula, S., M. J. VanGessel, and R. R. Mulford. 2004. Corn leaf architecture as a tool for weed management in two production systems. Weed Sci. 52:1026-1033.

[207] Santos, B. M., J. A. Dusky, W. M. Stall, D. G. Shilling, and T. A. Bewick. 1997. Influence of smooth pigweed and common purslane densities on lettuce yields as affected by phosphorus fertility. Proc. Fla. State Hortic. Soc. 110:315-317.

[208] Sardi, K. and I. Beres. 1996. Effects of fertilizer salts on the germination of corn, winter wheat, and their common weed species. Commun. Soil Sci. Plant Anal. 27:12271235.

[209] Sattin, M., M. C. Zuin, and I. Sartorato. 1994. Light quality beneath field grown maize, soybean, and wheat canopies - red:far red variations. Physiol. Plant. 91:322328.

[210] Schreiber, M.M. 1992. Influence of tillage, crop rotation, and weed management on giant foxtail (Setaria faberi) population dynamics and corn yield. Weed Sci. 40:645653.

[211] Schwinning, S. and J. Weiner. 1998. Mechanisms determining the degree of size asymmetry in competition among plants. Oecologia 113:447-455.

[212] Se'ne, M., T. Dore', and C. Gallet. 2001. Relationship between biomass and phenolic production in grain sorghum grown under different conditions. Agron. J. 93:49-54.

[213] Sexsmith, J. J. and U. J. Pittman. 1963. Effect of nitrogen fertilizers on germination and stand of wild oats. Weeds 11:99-101.

[214] Sharma, V. and N. N. Angiras. 1996a. Effect of row orientations, row spacings and weed-control methods on light interception, canopy temperature and productivity of wheat (Triticum aestivum). Indian J. Agron. 41:390-396.

[215] Sharma, V. and N. N. Angiras. 1996b. Light interception, weed growth and productivity of irrigated wheat as influenced by crop geometry and weed control methods. Indian J. Plant Physiol. 1:157-162.

[216] Sheaffer, C. C., Gunsolus, J. L., Grimsbo Jewett, J. and Lee, S. H. 2002. Annual Medicago as a smother crop in soybean. Journal of Agronomy and Crop Science 188, 408-416.

[217] Shrefler, J. W., J. A. Dusky, D. G. Shilling, B. J. Brecke, and C. A. Sanchez. 1994. Effects of phosphorus fertility on competition between lettuce (Lactuca sativa) and spiny amaranth (Amaranthus spinosus). Weed Sci. 42:556-560.

[218] Shrestha, A. and M. Fidelibus. 2005. Grapevine row orientation affects light environment, growth, and development of black nightshade (Solanum nigrum). Weed Sci. 53: 802-812.

[219] Sibuga, K. P. and J. D. Bandeen. 1980. Effects of various densities of green foxtail (Setaria viridis L. Beav.) and lambsquarters (Chenopodium album) on $\mathrm{N}$ uptake and yields of corn. E. Afric. Agric. For. J. 45:214-221. 
[220] Singh H. P., Batish D. R. and Kohli R.K. 2003. Allelopathic interactions and allelochemicals: New possibilities for sustainable weed management. Critical Reviews in Plant Sciences. 22: 239-311.

[221] Singh, H.P., D.R. Batish, S. Kaur, N. Setia, and R.K. Kohli. 2005. Effects of 2-benzoxazolinone on the germination, early growth and morphogenetic response of mung bean (Phaseolus aureus). Ann. Appl. Biol. 147:267-274.

[222] Sinoquet, H., Caldwell, R.M. 1995. Estimation of light capture and partitioning in intercropping systems. P.79-80. In H. Sinoquet, P. Cruz (Eds.) Ecophysiology of tropical intercropping. Inst. Natl. de la Recherche Agronomique (INRA), Paris.

[223] So, Y. F., M. M. Williams, II, J. K. Pataky, and A. S. Davis. 2009. Principal canopy factors of sweet corn and relationships to competitive ability with wildproso millet (Panicum miliaceum). Weed Sci. 57:296-303.

[224] Spies, J.M., T.D. Warkentin and S.J. Shirtliffe. 2011. Variation in field pea (Pisum sativum) cultivars for basal branching and weed competition. Weed Sci. 59:218-223.

[225] Steinbauer, G. P. and B. Grigsby. 1957. Interaction of temperature, light, and moistening agent in the germination of weed seeds. Weeds 5:175-182.

[226] Steinmaus, S., Elmore, C. L., Smith, R. J., Donaldson, D., Weber, E. A., Roncoroni, J. A. and Teasdale, J. R. 1993. Reduced-herbicide weed management systems for no-tillage corn (Zea mays) in a hairy vetch (Vicia villosa) cover crop. Weed Technol. 7, 879883.

[227] Stephen, O.D., Lydon, J., 1987. Herbicides from natural compounds. Weed Technol. 1 (2), 122-128.

[228] Supasilapa, S., Steer, B.T., Milroy, S.P., 1992. Competition between lupin (Lupinus angustifolia L.) and great brome (Bromus diandrus Roth.): development of leaf area, light interception and yields. Aust. J. Exp. Agric. 32, 71-81.

[229] Sweeney A. E., Renner K. A., Laboski C. and Davis A. 2008. Effect of fertilizer nitrogen on weed emergence and growth. Weed Sci 56:714-721.

[230] Teasdale, J. R. 1995. Influence of narrow row/high population corn (Zea mays) on weed control and light transmission. Weed Technol. 9:113-118.

[231] Teasdale, J. R. 1996. Contribution of cover crops to weed management in sustainable agricultural systems. J. Prod. Agric. 9, 475-479.

[232] Teasdale, J.R., 1998. Influence of corn (Zea mays) population and row spacing on corn and velvetleaf (Abutilon theophrasti) yield. Weed Sci. 46, 447-453.

[233] Teasdale, J. R. 2003. Principles and practices of using cover crops in weed management systems. In, R. Labrada (ed), Weed Management for Developing Countries. Food and Agriculture Organization of the United Nations (FAO), Rome, Italy. pp. 169-178. 
[234] Teasdale, J. R. and C. L. Mohler. 1993. Light transmittance, soil temperature, and soil moisture under residue of hairy vetch and rye. Agron. J. 85, 673-680.

[235] Teyker, R. H., H. D. Hoelzer, and R. A. Liebl. 1991. Maize and pigweed response to nitrogen supply and form. Plant Soil 135:287-292.

[236] Tollenaar M., Nissanka S.P., Aguilera A.,Weise S.F. and Swanton C.J. 1994. Effect of weed interference and soil nitrogen on four maize hybrids. Agron. J. 86, 596-601.

[237] Townley-Smith, L. and Wright, A. T. 1994. Field pea cultivar and weed response to crop seed rate in western Canada. Can. J. Plant Sci. 74: 387-393.

[238] Trujillo, E.E., 1985. Biological control of Hamakua pa-makani with Cercosporella sp. in Hawaii. In: Delfosse, E.S. (Ed.), Proceedings of the VI International Symposium on Biological Control of Weeds. Agriculture Canada, Ottawa, pp. 661-671.

[239] Tuncw, I. and S. Sahinkaya. 1998. Sensitivity of two greenhouse pests to vapours essential oils. Entomol. Exp. Appl. 86:183-187.

[240] Tworkoski, T., 2002. Herbicide effects of essential oils. Weed Science, 50: 425-431.

[241] Van Acker R. C., Swanton C. J. and Weise S. F. 1993. The critical period of weed control in soybeans [Glycine max (L.) Merr.]. Weed Sci 41: 194-200.

[242] Van Delden, A., L. A. Lotz, L. Bastiaans, A. C. Franke, H. G. Smid, R.M.W. Groeneveld, and M. J. Kropff. 2002. The influence of nitrogen supply on the ability of wheat and potato to suppress Stellaria media growth and reproduction. Weed Res. 42:429445 .

[243] Vandermeer, J., 1989. The Ecology of Intercropping. Cambridge University Press.

[244] van der Werf, A., M.V. Nuenen, A.J. Visser, and H. Lambers. 1993. Contribution of physiological and morphological plant traits to a species' competitive ability at high and low nitrogen supply. Oecologia 94:434-440.

[245] Vera C.L., Woods S.M. and Raney J.P. 2006. Seeding rate and row spacing effect on weed competition, yield and quality of hemp in the Parkland region of Saskatchewan. Can. J. Plant Sci. 86: 911-915.

[246] Verma, R., H. R. Agarwal, and V. Nepalia. 1999. Effect of weed control and phosphorus on crop-weed competition in fenugreek (Trigonella foenumgraecum). Indian J. Weed Sci. 31: 265-266.

[247] Vokou, D. 2007. Allelochemicals, allelopathy and essential oils: a field in search of definitions and structure. Allelop. J. 19: 119-134.

[248] Vrabel, T. E. 1983. Effects of suppressed white clover on sweet corn yield and nitrogen availability in a living mulch cropping system. Ph.D Thesis (Diss. abstr. DA 8321911), Cornell Univ., Ithaca, NY.

[249] Walker, R. H. and G. A. Buchanan. 1982. Crop manipulation in integrated weed management systems. Weed Sci. 30 (Suppl. 1): 17-24. 
[250] Wall, D. A. and L. Townley-Smith. 1996. Wild Mustard (Sinapsis arvensis) responses to field pea (Pisum sativum) cultivar and seeding rate. Can. J. Plant Sci. 76: 907-914.

[251] Wallace, D.H., K.S. Yourstone, P.N. Masaya and R.W. Zobel. 1993. Photoperiod gene control over partitioning between reproductive vs. vegetative growth. Theor Appl Genet 86: 6-16

[252] Wang G, Ehlers JD, Marchi ECS and McGiffen ME, Jr. 2006. Competitive ability of cowpea (Vigna unguiculata) genotypes with different growth habit. Weed Science 54: 775-782.

[253] Watson, A.K., 1991. The classical approach with plant pathogens. In: TeBeest, D.O. (Ed.), Microbial Control of Weeds. Chapman and Hall, New York, pp. 3-23.

[254] Watson, P. R., Derksen, D. A., Van Acker, R. C., and Blrvine, M. C., 2002. The contribution of seed, seedling, and mature plant traits to barley cultivar competitiveness against weeds. Proceedings of the 2002 National Meeting - Canadian Weed Science Society. 49-57.

[255] Watson, P.R., D.A. Derksen, and R.C. Van Acker. 2006. The ability of 29 barley cultivars to compete and withstand competition. Weed Sci. 54:783-792.

[256] Weaver S. E., Kropff M. J. and Groeneveld R. M. W. 1992. Use of ecophysiological models for crop-weed interference: the critical period of weed interference. Weed Sci 40: 302-307.

[257] Weiner, J. 1990. Asymmetric competition in plant populations. Trends Ecol. Evol. 5:360-364.

[258] Weiner, J., 1986. How competition for light and nutrients affects size variability in ipomoea-tricolor populations. Ecology 67, 1425-1427.

[259] Weiner, J., H. W. Griepentrog, and L. Kristensen. 2001. Suppression of weeds by spring wheat (Triticum aestivum) increases with crop density and spatial uniformity. J. Appl. Ecol. 38:784-790.

[260] Welles, J.M., Norman, J.M., 1991. Instrument for indirect measurement of canopy architecture. Agron. J. 83, 818-825.

[261] Weston, L. A. 1996. Utilization of allelopathy for weed management in agroecosystems. Agron. J. 88:860-866.

[262] Weston, L. A. 2005. History and current trends in the use of allelopathy for weed management. Hort. Technology 15, 529-534.

[263] Weston, L.A., R. Harmon, and S. Mueller. 1989. Allelopathic potential of sorghumsudangrass hybrid (sudex). J. Chem. Ecol. 15:1855-1865.

[264] Westra, E. P. 2010. Can Allelopathy be incorporated into agriculture for weed suppression? http,//www.colostate.edu/Depts/Entomology/courses/en570/papers_2010/ westra.pdf. 
[265] White R. H., Worsham A. D. and Blum U. 1989. Allelopathic potential of legume debris and aqeous extracts. Weed Sci. 37, 674-679.

[266] Williams, W.A., Loomis, R.S., Duncan, W.G., Dovert, A., Nunez, F., 1968. Canopy architecture at various population densities and the growth of grain of corn. Crop Sci. 8: 303-308.

[267] Wortmann, C.S. 1993. Contribution of bean morphological characteristics to weed suppression. Agron. J. 85:840-843.

[268] Wu, H., J. Pratley, D. Lemerle, and T. Haig. 2000. Evaluation of seedling allelopathy in 453 wheat (Triticum aestivum) accessions against annual ryegrass (Lolium rigidum) by equal-compartment-agar method. Aust. J. Agric. Res. 51:937-944.

[269] Wu, H., J. Pratley,W. Ma, and T. Haig. 2003. Quantitative trait loci and molecular markers associated with wheat allelopathy. Theor. Appl. Genet. 107:1477-1481.

[270] Wu, H., pratley, J., Lemerle, D. and Haig, T. 1999. Crop cultivars with allelopathic capability. Weed Research. 39: 171-180.

[271] Wu, H., Pratley, J., Lemerle, D., Haig, T. and Verbeek, B. 1998. Differential allelopathic potential among wheat accessions to annual ryegrass. In. Proceedings 9th Australian Agronomy Conference, Wagga Wagga, Australia, 567-571 .

[272] Yenish, J.P., J.C. Doll, and D.G. Buhler. 1992. Effects of tillage on vertical distribution and viability of weed seed in soil. Weed Sci. 40:429-433.

[273] Yoshida, H., Iida, T., Sato, K., Moharramipour, S. and Tsumuki, H. 1997. Mapping a gene for gramine synthesis. Barley genetics newsletter 27, 22-24.

[274] Yoshida, H., Tsumuki, H., Kanehisa, K. and Corucuera, L. J. 1993. Release of gramine from the surface of barley leaves. Phytochemistry 34, 1011-1013.

[275] Zhao, D.L., Atlin, G.N., Bastiaans, L., Spiertz, J.H.J., 2006. Cultivar weed-competitiveness in aerobic rice: heritability, correlated traits, and the potential for indirect selection in weed-free environments. Crop Sci. 46: 372-380. 
